\title{
WALKING IN A WINTER WONDERLAND? AN ASSESSMENT OF WINTER MAINTENANCE AND PHYSICAL ACTIVITY FEATURES IN SMYTHE PARK, TORONTO
}

$$
\text { by }
$$

\section{Maria Bianchi}

BA (Hons.), University of Toronto, 2011

\author{
A Major Research Paper \\ presented to Ryerson University \\ in partial fulfillment of the requirements for the degree of \\ Master of Planning \\ in \\ Urban Development
}

Toronto, Ontario, Canada, 2014

(C) Maria Bianchi 2014 


\section{Author's Declaration}

I hereby declare that I am the sole author of this major research paper. This is a true copy of the major research paper, including any required final revisions, as accepted by my examiners.

I authorize Ryerson University to lend this major research paper to other institutions or individuals for the purpose of scholarly research.

I further authorize Ryerson University to reproduce this major research paper by photocopying or by other means, in total or in part, at the request of other institutions or individuals for the purpose of scholarly research.

I understand that my major research paper may be made electronically available to the public. 


\title{
WALKING IN A WINTER WONDERLAND?
}

\section{AN ASSESSMENT OF WINTER MAINTENANCE AND PHYSICAL ACTIVITY FEATURES IN SMYTHE PARK, TORONTO}

\author{
(C) Maria Bianchi, 2014 \\ Master of Planning \\ in \\ Urban Development \\ Ryerson University
}

\begin{abstract}
Objective. To determine how the features, conditions, and maintenance of a low-income park affect the use of the park for physical activity during the winter months.
\end{abstract}

Method. Direct observation of park use; assessment of park quality based on a developed assessment tool; and supplementary surveys with park users.

Results. The park lacked winter park features (e.g. ice rink, tobogganing hill) and supporting amenities (e.g. washrooms, rental facilities). There was evidence of winter maintenance, however, it was inconsistent: most trails were cleared of snow on all visits, but large ice patches were present and had not been cleared. The park was used primarily for walking and dog walking, although respondents noted that the lack of maintenance in the park affected if they used it for physical activity.

Conclusion. Winter maintenance of parks and the presence of winter features affect park use, with snow removal, ice removal, and the presence of bathrooms having a strong influence on physical activity levels in the winter months. Park planners should consider 
year-round maintenance and programming in order to promote engagement in physical activity during all seasons.

Key words:

winter maintenance of parks; winterization; parks and physical activity; health equity 


\section{Acknowledgements}

I would like to thank my supervisor, Christopher De Sousa, for his guidance and support in writing this Major Research Paper. I would also like to thank my second reader, Zhixi Zhuang, for reviewing my work and providing extremely helpful feedback. 


\section{Dedication}

To my parents, who made my 7 years of post-secondary education possible, and who have supported me throughout the entire journey. Thank you. Without you, I would never have been able to pursue my dreams.

And to BC, who encouraged me to live a healthy and active lifestyle (and supported me during all the nights that I skipped the gym to stress out about this paper instead). Your passion for health and fitness was the source of inspiration for this MRP, and your constant support has been vital in helping me reach the end! 


\section{Table of Contents}

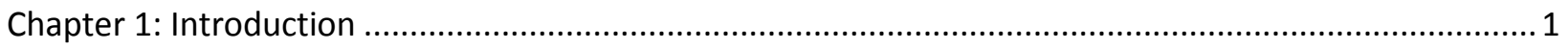

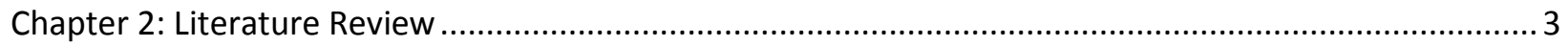

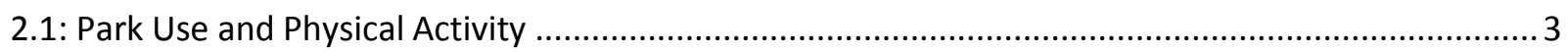

2.2. Gaps in the Literature: Winter Park Features, Conditions, \& Use ................................................. 5

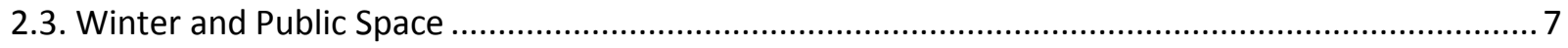

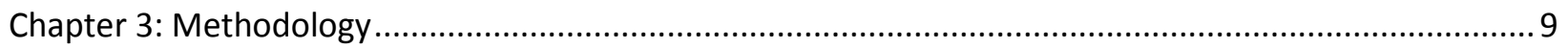

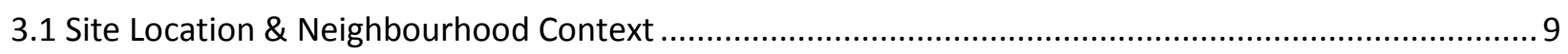

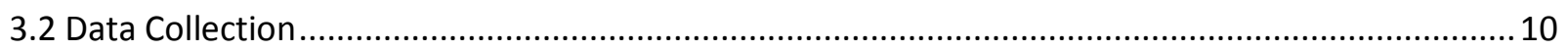

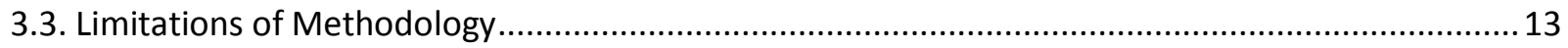

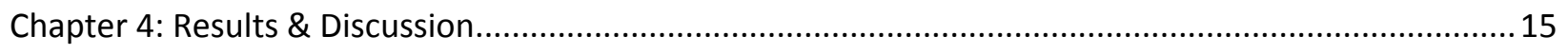

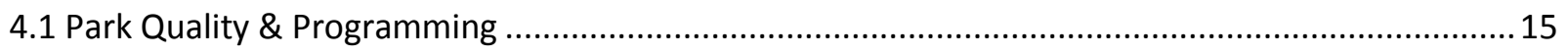

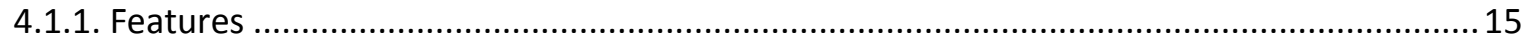

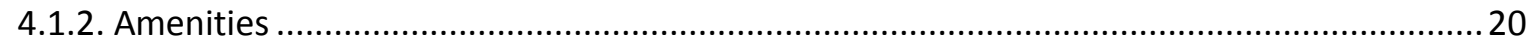

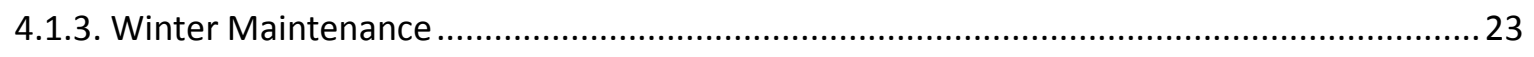

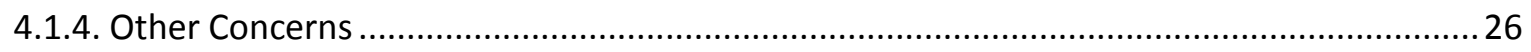

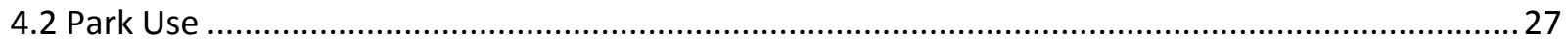

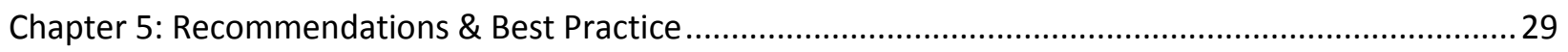

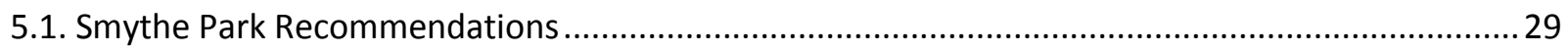

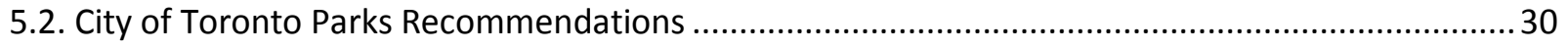

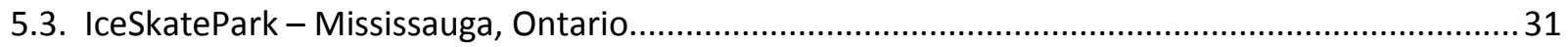

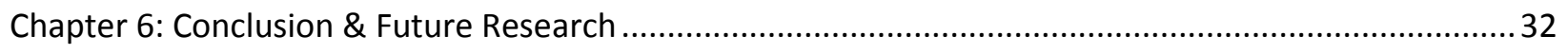

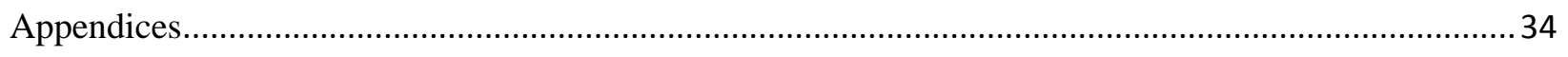

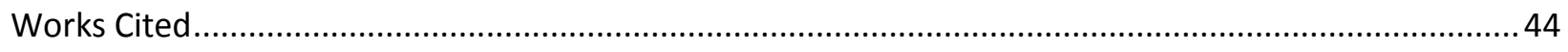

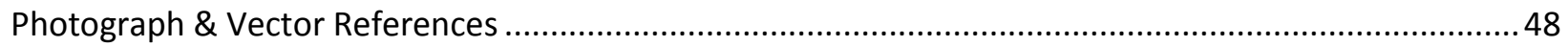

\section{List of Figures}

Figure 1: site map of Smythe Park's location .................................. 10

Figure 2: division of park for analysis purposes .............................. 10

Figure 3: summary of assessment of Smythe Park .............................. 17 
Figure 4: looking east on the main formal trail ................................. 18

Figure 5a: an example of the cracking in the trails ............................. 18

Figure 5b: an example of the cracking in the trails .............................. 18

Figure 6: map of dedicated (formal) walking trails \& informal walking trails ................. 19

Figure 7a: example of frequently travelled informal trail .............................. 20

Figure 7b: informal trail connecting formal, paved pathways ........................... 20

Figure 7c: fenced and ploughed informal trail ........................................ 20

Figure 7d: example of less popular informal trails beside Humber River tributary .............. 20

Figure 8: lack of green coniferous vegetation .......................................... 21

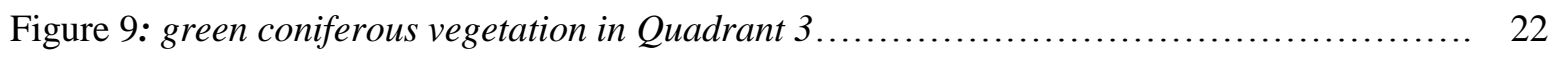

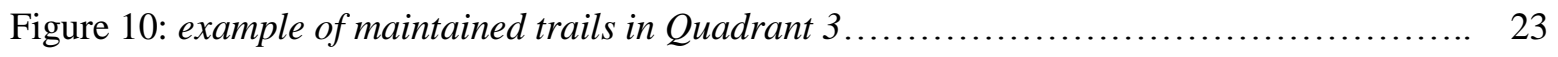

Figure 11: example of large, uncleared ice patches on dedicated walking trails................ 23

Figure 12: large puddle covering part of the vehicular/ pedestrian entrance into Smythe Park... 24

Figure 13: example of danger signs found in Smythe Park.............................. 25

Figure 14: distribution of uses observed at Smythe Park ................................ 27 


\title{
Chapter 1: Introduction
}

\author{
"by providing low-cost and accessible opportunities for \\ physical activity, parks are used by a vast majority of people \\ and thus can enhance physical activity at the population level \\ across ages, cultures, ethnicities, genders, income levels, and \\ abilities”- Bai, Stanis, Kaczynski, \& Besenyi, 2013, p. S39.
}

The built environment, and particularly the presence of parks and open green spaces, has been cited as having an important influence on physical activity in urban areas. Urban parks have the potential to improve health in cities by increasing physical activity levels across all populations, thereby helping to reduce rates of obesity, heart disease, and other chronic illnesses (Coombes, Jones \& Hilldson, 2010). Given the proven health benefits associated with park use, and the fact that "parks provide affordable places where people of all ages and backgrounds can be moderately or vigorously physically active" (Board of Health, 2011, p. 5), parks are viewed as a means of reducing health disparities between high and low-income neighbourhoods. In Toronto specifically, low-income individuals tend to have higher hospitalization and death rates due to heart disease and diabetes compared to high-income individuals (Board of Health, 2011). Lowincome Torontonians have also been demonstrated to participate in less Board of Health, 2011).

Despite the health benefits that park space can provide to low-income communities, it has been demonstrated that low-income residents tend to use parks less than those in high-income areas, (Cohen, Han, Derose, Williamson, Marsh, Rudick, McKenzie, 2012), thereby perpetuating the gap in health equity between low-income and high-income neighbourhoods. Further complicating this trend is Toronto's seasonal climate, and the harsh winters the city experiences. Activity tends to decline in the winter months; for low-income communities that have less access to, and reduced financial means for, indoor recreational facilities, a lack of winterized park space can only act to make this discrepancy worse. In order to properly inform park planning so as to increase park use in the winter months and reduce the health equity gap, the reasons behind why this discrepancy exists must be understood. As such, the following research engaged in an exploration of winter park conditions, features, and use in a low-income park. The study was undertaken during the month of February in Smythe Park, located in a low-income 
neighbourhood of Toronto. The main research methods combined direct observation of park use, surveying/informal interviewing of park users, and direct observation of park conditions/features based on a developed assessment tool. The research was guided by four main questions:

1. How are parks in low-income neighbourhoods used for physical activity, specifically in the winter?

2. How are the parks programmed? What is the quality of the parks? (i.e. Are the parks winterized? Are they maintained)?

3. Does the quality \& programming of the park affect if/how they are used for physical activity in the winter?

4. How can the parks be improved to increase their use for PA in the winter months? 


\section{Chapter 2: Literature Review}

A plethora of literature exists that broadly explores if and how parks can improve citizen's physical and mental health. The following review of literature is divided into three main sections. The first section will discuss the studies that explore the relationship between parks and physical activity specifically, including primarily those studies that look at access, features, and conditions. The second section will explore the significant gap in the literature that exists in relation to studies that look at parks during the winter months. The final section will summarize the existing theoretical literature surrounding the idea of "winter cities" and the importance of designing cities with winter in mind.

\section{1: Park Use and Physical Activity}

Park use in general has been cited as playing a role in improving local population health, by, for example, preventing and/or reducing obesity (Blanck et al., 2012). Such health benefits are realized primarily through an increase in physical activity levels as a result of the use of such parks (Han, Cohen, \& Mckenzie, 2013; Kacynski et al., 2009). Many studies suggest that access to parks - both in terms of the availability and proximity - is a key contributor to such increased physical activity levels (McCormack, Rock, Toohey, \& Hignell, 2010; Roemmich et al., 2006). Kacynski and Henderson (2007) conducted a review of 50 quantitative studies that explored the relationship between exercise and parks, and found that proximity was almost always associated with increased physical activity (as cited in Lee \& Maheswaran, 2010): as distance increases, the use of parks for physical activity decreases (Coombes, Jones \& Hillsdon, 2010) Cohen et al. (2006) determined that adolescent girls who live near parks had increased physical activity levels compared to girls living in areas with fewer parks. In their study in Perth, Australia, Giles-Corti et al. (2005) found that having access to large public spaces increased the levels of walking in urban areas amongst adults aged 18 to 59 years. Kaczynski et al. (2009) determined that the availability of more parks in an area was conducive to increased participation in moderate-tostrenuous physical activity.

It is important to note that, while access to parks may increase physical activity levels, engagement in physical activity amongst different socioeconomic groups is not always equal. As Floyd, Taylor, \& Whitt-Glover (2009) argue, "residents of low-income communities of color are 
usually found to have lower physical activity, and this may be due partly to a disparity in access to parks and other recreation environments" (p. S156). Studies that explore the location of recreational and commercial physical activity-related facilities in general find that such facilities are less likely to be located in low-income neighbourhoods, (Gordon-Larsen, Nelson, Page, \& Popkin, 2006; Powell, Slater, Chaloupka, \& Harper, 2006), although parks tend to be slightly more equitably distributed (Moore, Roux, Evenson, McGinn \& Brines, 2008; Wen, Zhang, Harris, Holt \& Croft, 2013). Even in light of the more equitable distribution of parks verses other recreational facilities, it has been found that low-income residents tend to use parks less than those in high-income areas (Cohen et al., 2012).

It has been argued that "although lack of access may be a driving factor to lower rates of physical activity in some deprived areas, there are likely additional qualitative elements of the physical activity resources that have not been well described or documented" (Lee, Booth, Reese-Smith, Regan, \& Howard, 2005, n.p.). Given the finding that, despite relatively equitable access, parks in low-income areas are used less than in high-income areas, it is important to consider what other features of parks may influence their use (or lack thereof). Bedimo-Rung, Mowen \& Cohen (2005) suggest that, beyond access, there are four other characteristics that mediate the relationship between parks and physical activity, two of which include features and conditions. 'Park features' includes the physical facilities (tennis courts, picnic tables, etc.) available at the park. In examining the importance of park size, features and proximity for physical activity in four neighbourhoods in Ontario, Kacyzynski, Potwarka, and Saelens (2008) determined that park features, specifically the presence of trails, had the strongest correlation with physical activity in comparison to size and proximity. Moreover, those parks which provided a larger number of facilities and supporting amenities were more likely to be used for physical activity. In Cohen et al.'s (2006) study mentioned above, it was not only park access that increased physical activity levels amongst adolescent girls, but, more specifically, access to parks with walking amenities and features that promote physical activity. In a review of 21 qualitative studies, it was found that the presence and number of specific attributes and features of parks - including trails, sidewalks, paths, sports fields/tracks, swimming areas- influenced park use for physical activity (McCormack, Rock, Toohey, \& Hignell, 2010). In addition, a lack of maintenance of such features (i.e. the conditions of the park) has been cited as a negative 
influence on the use of parks (McCormack et al., 2010), and positive perceptions of a park's quality are associated with increased park-based physical activity (Bai et al., 2013).

\subsection{Gaps in the Literature: Winter Park Features, Conditions, \& Use}

Understanding the influence that park features and conditions have on park use can be a key factor in explaining the differential use of parks for physical activity in low-income and high-income neighbourhoods (Cohen et al., 2012); however, as Bedimo-Rung et al. (2005) note, "little work has been done to distinguish among the potentially varying conditions of [park] features" (p. 164). A gap in the literature exists, as only a small number of studies have explored how facilities and conditions may differ between low-income and high income neighbourhoods, and how this affects park use.

Equally significant is the fact that, despite findings that suggest there is a decrease in physical activity levels amongst various populations during the winter months (Tucker \& Gilliland, 2007), even fewer studies have actually assessed the features, conditions, or use of local parks during the winter months. Most studies that investigate the relationship between park use and physical activity specifically are done so during the spring and summer months, and/or are undertaken in cities that have a warm climate. Even with the emergence of the Livable Winter City Association in 1984 (Gappert, 1987) - a concept that will be explored below - very limited literature was published on the winter use and conditions of parks throughout the 1980s. As McLean, Smith, Larsen (1989) note, at the time of their study, "less than six articles have appeared on outdoor winter activities or urban winter facilities in the last seven years" (p. 52-53) in major park and recreation journals. For the purpose of this study, only two studies were found that related to park use in the winter. McLean et al. (1989) explored the availability of winter facilities and programs, and winter participation levels in 61 Canadian and American cities. They found that ice rinks and cross-country trails were the most common outdoor facilities. Moreover, over the course of three years, $55 \%$ of the respondents suggested that their participation in winter recreation had increased. Boivin (1988) engaged in a survey- and direct observation-based study in High Park, Toronto, and determined that the park was primarily used for walking, jogging, dog walking, and hiking during the winter months. Moreover, besides the natural environment of High Park, the "best liked" feature of the park was the skating rink. Finally, $12 \%$ of the respondents disliked the dangerous walking conditions on trails after a heavy snow or rainfall, 
and sidewalk snow removal was the most important (43\%) feature for encouraging use of the park (Boivin, 1988).

In keeping with the trends of the 1980s, a scarce number of recent studies reviewed for the purpose of this study explored the conditions and/or winter-specific features of park space, and how these affect park use during the winter months. The few current winter-based studies that do exist have examined how national parks are used, the characteristics of park users, and what improvements should be made to the park from the perspective of park users (Simic, 2007), and the positive psychological effects associated with walking in urban parks in the winter (Song et al., 2013). More recently, a not-for-profit group named Ice Park Group Inc. released the results from the survey they conducted in Mississauga, Ontario, which was used to gauge interest in the potential development of a large outdoor public ice skating park.

In Simic's (2007) study of Canadian Rocky Mountain Parks, the author learned that, for those who engaged in cross-country skiing, the primary reason was to stay physically-fit during the winter months, combined with the experience of being in nature. When users were asked about their concerns with the park, and what aspects needed improvement, findings were similar to those of Boivin (1988) in that "trail maintenance and maps and signage for the trails were the biggest concern" (p. 28). A second item that needed significant maintenance was the washrooms: many respondents felt that park management needed to provide better washrooms, and maintain the existing ones. Two other notable suggestions by park users were the provision of rental services in the park and for management to reduce park entrance fees, because you "want [the] park to be used by as many people" (p. 28).

Song et al. (2013) compared psychological data that was collected from an experiment where males were instructed to walk through an urban park and a city area during the month of November. From these results, the authors determined that "walking in the urban park improved mood and decreased negative feelings and anxiety" (p.1). Such results suggest that not only are there physical health benefits associated with park use, but there are also mental health benefits associated specifically with winter use.

The survey conducted by Ice Park Group Inc, found a high interest in having an ice skating facility in Mississauga, with $85 \%$ of respondents who know how to skate agreeing that 
they would visit once a year to skate. In relation to the creation of the park to increase and motivate physical activity, "of 110 people who were asked about the role of existing recreational facilities in inspiring more people to become physically fit, 14\% said that IceSkatePark was either not needed or it wouldn't help. The remainder said IceSkatePark should supplement existing recreation facilities in Mississauga." (Ice Park Group Inc., 2013, p. 2, emphasis added). The plans for the IceSkatePark facility will be further explored in Chapter 5.3.

\subsection{Winter and Public Space}

Although there are few studies that explore and substantiate the relationship between park conditions, park features, and the use of parks for physical activity during the winter months, there does exist literature that looks more broadly at the theoretical principles behind designing public spaces, including parks, with winter in mind. The concept of a winter city, developed by the Livable Winter City Association, describes a city which experiences seasonal variations; extended periods of cold, below-freezing temperatures during a large portion of the year; precipitation in the form of snow; and limited hours of daylight/sunshine (Pressman, 1988). More significantly, a city that has embraced the concept of the "winter city" is one which has at the center of its planning initiatives the "goal [of] address[ing] the problems of snow and cold while enhancing the advantages, opportunities, and beauty of the winter season" (Coleman, 2010, p. 11). A livable winter city is one whose public spaces and buildings have embraced winter in their design, and have been planned for year-round usability (Pressman, 1996).

One aspect of a livable winter city is the provision of parks and outdoor recreational facilities that allow "children...to play, grown-ups to sit, talk, read, play games, etc., outdoors in a pleasant, green environment protected against undesirable climatic conditions" (Pressman, 1988, p. 13). As Pressman (1987) notes, in a survey conducted amongst planning directors, a lack of attractive outdoor winter facilities was one issue they identified as needing significant attention and improvement. Some important design aspects that are typical and vital for open spaces in a winter city, and which invite citizens to actually engage in activity in the space, include:

- $\quad$ use of bold colors on buildings to brighten and warm a space (Pressman, 1996);

- $\quad$ use of coniferous vegetation to provide greenery and protection from cold winds (Pressman, 1996; Pressman, 1988; Coleman, 2008); 
- provision of programming that encourages winter physical activity (Pressman, 1988), using the existing landscape to provide these facilities (e.g. lakes converted to ice rinks) (Coleman, 2010);

- provision of heated washrooms/dressing rooms;

- provision of separated sidewalks and roadways to prevent spray of slush (Coleman, 2008); and

- conversion of existing pedestrian trails to multi-use trails for snowshoeing, walking, cross-country skiing (Coleman, 2008; Coleman, 2010)

Many of these design aspects are related to park features which, as mentioned, can play an important role in influencing the use of parks for physical activity. Moreover, the guidelines for parks in the winter cities literature generally do not discuss winter maintenance (or the "conditions") of the park; however, given the importance that maintenance and park conditions have on the use of parks, as noted in existing literature on physical activity and park use, this is also a vital factor to explore.

This study seeks to fill the significant gap in the literature by exploring the use of local parks in a low-income neighbourhood during the winter, and the facilities and conditions of such parks. This is such an important aspect of park planning to explore because "the presence of parks in poor and minority areas suggests that improving the type and quality of resources in parks could be an important strategy to increase physical activity and reduce racial/ethnic and socioeconomic disparities” (Moore, Roux, Evenson, McGinn, \& Brines 2008, p. 16.). Ultimately, the goal of this research is to provide informed recommendations - based on existing winter design guidelines and the primary findings of this study - on how to program parks so as to increase physical activity amongst low-income communities, specifically in the winter months. 


\section{Chapter 3: Methodology}

\subsection{Site Location \& Neighbourhood Context}

The study was conducted in Smythe Park, a 15.3 hectare park located at 175 Scarlett Road in the City of Toronto (City of Toronto, 2014a). The park is bounded by Scarlett Road to the west, Black Creek Boulevard to the north, Jane Street to the east, and Edinborough Court/Haney Avenue to the south (Figure 1). Running east/west through the center of the park is Black Creek Trail, as well as a tributary of the Humber River. The site is accessible by car from Scarlett Road, and there are also pedestrian access points on the north, south and east side of the park. The park has been designed with summer-specific programming including a splash pad, a playground, an in-ground pool and associated washrooms/change rooms, and a baseball diamond.

The park itself is located in the Rockcliffe-Smythe neighbourhood (neighbourhood 111), which is bounded by Eglinton Avenue West to the north, Weston Road to the east, the Canadian Pacific Railway Line to the south, and the Humber River to the west. The Rockcliffe-Smythe neighborhood has been classified as a low-income area (Glazier, Booth, Gozdyra, Creatore, Tynan, 2007; GHK, 2005): In 2006, the median income of private households was $\$ 45514$ (City of Toronto, 2014a). Although the distribution of low-income private households varies throughout the neighbourhood - with some areas having few to none- the area directly surrounding Smythe Park has a high concentration of low-income private households (between 222 and 4222 households) (City of Toronto, 2008). Given the focus of the study on low-income parks in particular, Smythe Park was selected due to its economic profile. 


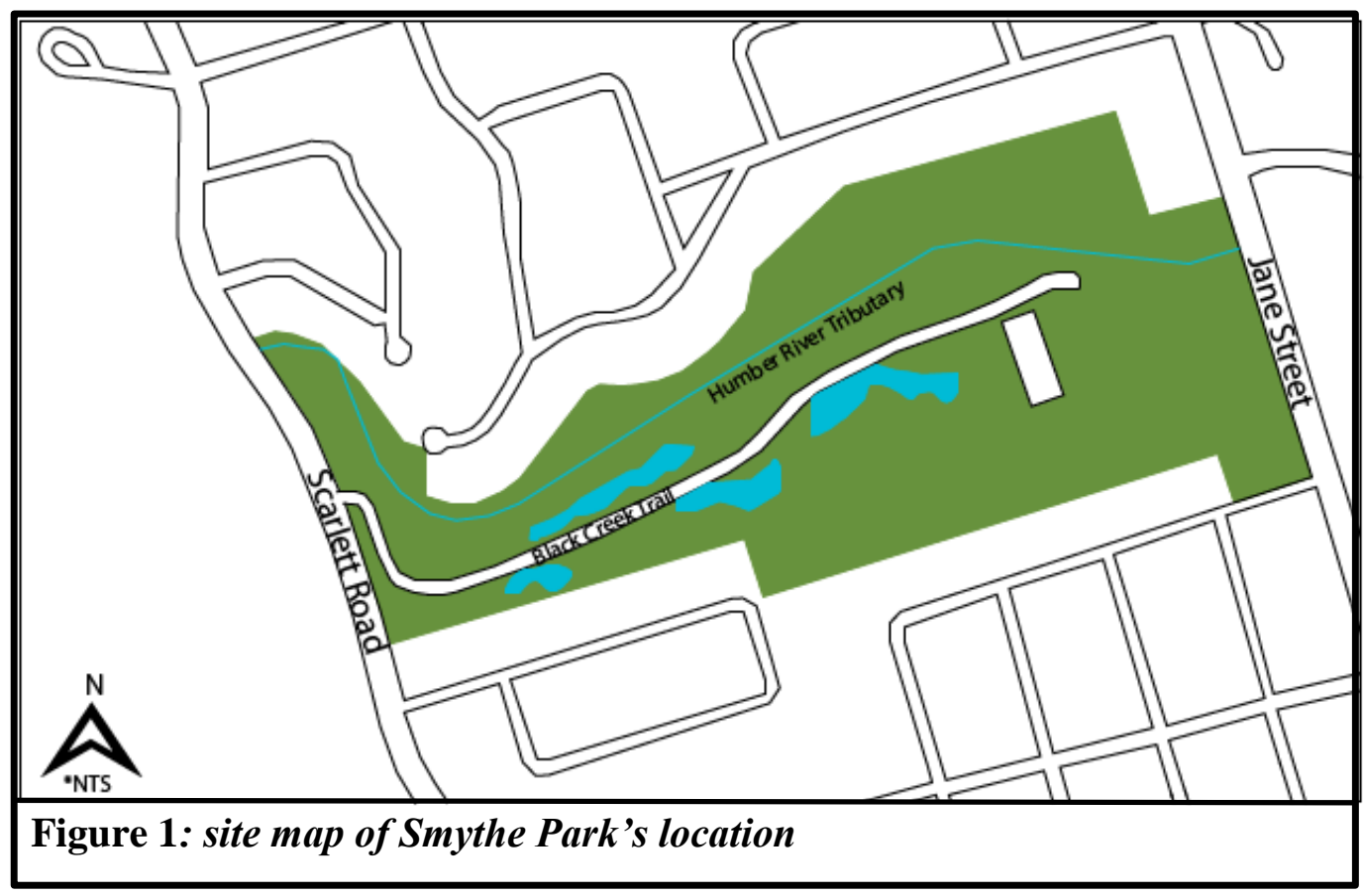

\subsection{Data Collection}

In order to ensure proper coverage of the entire park, the park was divided into three quadrants (Figure 2). Quadrant 1 covered the area from Scarlett Road to point at which Black Creek Trail begins to curve into an east/west travelling road. Quadrant 2 covered the area from where Black Creek Trail begins to travel in an east/west direction to its termination just east of the outdoor pool; this quadrant was divided in the center by an accessible pedestrian bridge. Quadrant 3 covered the remaining area of the park, terminating at Jane Street. During each visit, an equal amount of time (between 30 and 40 minutes) was spent in each quadrant.

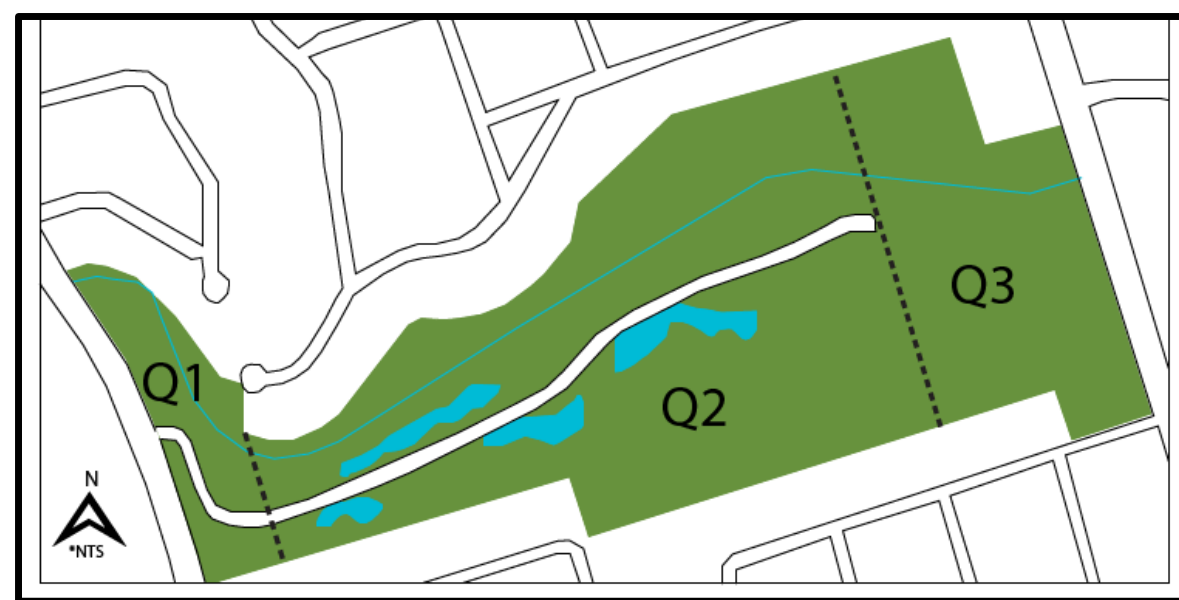

Figure 2: division of park for analysis purposes 
The park was frequented four times over the course of two weeks in February 2014. The first site visit took place on Sunday, February $16^{\text {th }}$ from 2:00 pm to 4:00 pm. Weather conditions at the time of the visit were sunny with some falling snow and a temperature of $-9^{\circ} \mathrm{C}$. The second site visit occurred on Monday February $17^{\text {th }}$ - a statutory holiday - from 11:00 am to 1:00 pm. Weather conditions at the time of the visit were sunny, with a temperature of $1^{\circ} \mathrm{C}$. The third visit took place between 3:00 pm and 4:30 pm on Wednesday, February $19^{\text {th }}$. Weather conditions at the time of the visit were overcast and a mild $3^{\circ} \mathrm{C}$. The final visit occurred on Tuesday, February $25^{\text {th }}$ between 9:00 am and 10:30 am. Weather conditions at the time of the visit were sunny, with a temperature of $-8^{\circ} \mathrm{C}$.

Data collection was divided into three main components: direct observation of park conditions, direct observation of park use, and participant surveys/informal interviews. In order to assess the conditions of the park, an assessment criteria (Appendix A) was created, which was loosely based on the Physical Activity Resource Assessment (PARA) Instrument. The PARA tool was developed by a number of scholars with a diverse background in Health and Human Performance, Psychology, and Geography (Lee et al., 2005). It is “a brief, one-page, check-box instrument used to assess the type, features, amenities, quality and incivilities of a variety of physical activity resources" (Lee et al., 2005). The tool has proven to have good reliability (rs > .77) (Lee et al., 2005). The initial testing of the tool to compare low-income and high-income neighbourhood parks suggested that:

Although PA resources were similar in number, features and amenities, the overall appearance of the resources in [lower-income] neighborhoods was much worse as indicated by substantially worse incivilities ratings in [lower-income] neighborhoods. The more comprehensive assessment, including features, amenities and incivilities, provided by the PARA may be important to distinguish between PA resources in lower and higher deprivation areas (Lee et al., 2005, n.p.)

As such, the PARA tool was considered a vital tool for this research, as an assessment of the quality of a low-income park is what is under study. However, while a useful tool, the items in the PARA Instrument are primarily focused on summer programming and maintenance (i.e. the presence of tennis courts, soccer fields, pools, overgrown grass, etc.). As such, for the 
purpose of this study, the PARA instrument checklist and operational definitions were modified to include winter maintenance and winter programming. These modifications were informed by a best practice review of winter design and maintenance guidelines, as well as the theoretical concept of the "livable winter city".

The modified tool was organized under three main categories: features, amenities, and winterization/winter maintenance. Each item under the three categories was rated on a scale of 0 to 3, with 0 being "not present", 1 being "poor", 2 being "mediocre" and 3 being "good". The rating for each criteria was associated with an operational definition that contextualized the meaning of the rating (Appendix B). The "features" category related to the presence and general quality of winter-specific facilities in the park, which could directly encourage engagement in physical activity. Such facilities included dedicated trails for walking, hiking, cross-country skiing or snowshoeing; an ice rink for skating or hockey; a curling rink; sledding hills; and sidewalks. The second category, "amenities", related to both the design aspects of the park (namely access points and vegetation) and their quality, as well as the presence and quality of supporting facilities that, although may not directly encourage physical activity, provide an environment that motivate people to stay in the park longer, and could thus influence people's decision to use the park. These facilities included bathrooms, change rooms, rental equipment facilities, and shelters. The final category looked at the overall winterization and winter maintenance of the park, namely ice \& snow removal, snow storage, and signs/updates on park conditions.

The modified PARA tool was only employed during the first site visit to the park. Each quadrant was observed for 40 minutes, in which I walked around both the perimeter and interior of each area, excluding unsafe areas such as near water bodies. For areas that were deemed dangerous, observations were made from a safe distance. Although the assessment tool was only formally utilized on the first visit, the original assessment was consulted in subsequent visits, and any changes in initial observations were noted. For example, if the trails were cleared of snow on the first visit, they received a high rating in the snow removal category; however, if a large storm occurred in between the first visit and subsequent visits, and the trails were not cleared, this was incorporated into the original rating of the related item. The total score from the three quadrants were calculated for each item. If the total rating fell between 2 and 3, it was rated as poor 
(overall); if it fell between 4 and 7, it was rated as mediocre (overall); if the category received a total rating of 8 or more, it was rated good (overall). A total score of 0 indicated that the item was not present.

For the direct observation of park use, a simple tally of each use observed was recorded. During the first site visit, the uses were noted while walking around each quadrant and analyzing the park conditions. For subsequent visits, the majority of the 30-40 minutes in each quadrant was spent sitting on a bench in the center of the quadrant and tallying park uses. Because the park is not a high-volume park, and because activities were limited to walking, dog walking, jogging, or playing in the snow, this method of observation was sufficient.

The park assessment and direct observation of park use was supplemented by the surveying/informal interviewing of park users. A survey was created (Appendix C) and approved by the Research Ethics Board at Ryerson University. The aim was to survey ten participants in total, regardless of which quadrant they were observed in. The questions in the survey pertained to how often participants used the park, what activities they participated in while visiting the park, and what improvements could be made to increase their use of the park for physical activity during the winter months. While making direct observations of park use, every $5^{\text {th }}$ user observed was approached to fill in the survey. Although participants filled in the survey themselves, I also noted any additional comments/concerns they raised during informal conversations.

To supplement the findings and recommendations of this study, the City of Toronto Parks and Recreation department was contacted. A representative from the department answered questions related to the winterization of existing parks in Toronto via e-mail.

\subsection{Limitations of Methodology}

The study methodology was generally limited by a lack of manpower, funding and time. Because of the size of the park, and the fact that only I was conducting both an assessment of the park and observations about park use, there is the possibility that some park users and some areas were unintentionally excluded from the study. Dividing the park into three quadrants and spending equal time in each quadrant was in attempt to mitigate the risk of excluding park users and areas. Moreover, given more time and a larger research team, the study would have benefited 
from an analysis of other parks in low-income areas, as well as parks in higher-income areas that have been programmed for winter, in order to allow for comparisons.

The PARA instrument has proven to have good reliability as an assessment tool; however, most researchers who utilize the PARA tool undergo both in-house and field training (Active Living Research, 2014). In the case of this study, I did not receive any formal training in using the PARA tool. Moreover, the tool was modified to suit this particular study. As such, the reliability of the PARA tool in this instance is unknown; however, the strength is that it provided a simple and systematic way to assess the park and ensure consistency over different site visits.

Finally, there was a very low response for the survey portion of this research. Given the nature of the winter season and the cold temperatures, many people did not want to stop to fill out the survey, and some of those who did appeared to rush through it. Moreover, it was difficult to interrupt people who appeared to be engaging in physical activity, especially jogging. Although the focus of the survey was to collect data from low-income park users, because of the low response rate, respondents ranged significantly in their economic background. As such, it was difficult to make connections between income level, park use, and suggestions for improvement directly. The study had to rely on the fact that the park is geographically located in a low-income community. With a larger time and financial budget, surveys could have been disseminated through the mail or online to households in the vicinity of the park, in order to increase the response rate and collect enough data that could be statistically analyzed and generalized. 


\section{Chapter 4: Results \& Discussion}

As Pressman (1996) notes, "there exists a need to encourage and promote year-round outdoor activity of both an active and passive nature - as a counterthrust to prolonged indoor confinement - especially in urban areas where public and semi-public spaces should be used to capacity throughout the outdoor season" (p. 528). This sentiment is echoed in Walljasper (2010): "if there are people out, other people will come out too to see what's going on. But there has to be a reason to be outside - a market, ice skating, music, decorative lighting or just a good place to hang out when it's cold. No one will stay outdoors to stare at an empty plaza" (p. 7). As such, the following section assesses and analyzes the features, amenities and maintenance - or the qualities that encourage and promote outdoor activities - of Smythe Park.

\subsection{Park Quality \& Programming}

The following observations are the results of the assessment of Smythe Park based on the assessment tool created. A summary of the ratings for each of the items on the assessment checklist can be found in Figure 3. To supplement the findings on both park quality and use, a total of four park users were interviewed/surveyed for this study. Three of the respondents were male and one was female. The ages of the respondents were 20 (male), 43 (male), 51 (male), and 64 (female). The total family income of the participants ranged from $\$ 25,000$ to over $\$ 75,000$. All four respondents reported White/European American as their ethnic identity. In regards to general physical activity levels, three of the four respondents reported being physically active at least twice a week, while the fourth respondent reported he did not engage in physical activity.

\subsubsection{Features}

As noted above, existing studies on park use and physical activity during warmer seasons have demonstrated a relationship between park features and park use; that is, the provision of specific features such as walking trails, sidewalks, and sports fields is cited as an important influencing factor for the use of parks for physical activity. In terms of winter park features, Walljasper (2010) argues that "parks and plazas play a big role in fostering public activity 12 months a year, providing people with places to sled, cross-country ski, ice skate or just mingle" (p.7). Moreover, Norman Pressman (1996) has argued that one of the main interventions that planners and policymakers must take into consideration is the provision of winter-oriented 
outdoor amenities, including ice rinks for hockey and skating, ski jumps, as these "amenities will promote "fitness" and "sports" programs" (p. 525). Despite the importance that park features in general, and the provision of winter programming specifically, has for engaging people in physical activity during the winter months, Smythe Park lacked any form of winter-specific programming. The only programming that was present was a swimming pool, a splash pad, a baseball diamond, and playground, which are all summer-specific activities. Moreover, in e-mail correspondence with the City of Toronto, it was noted that there are no current plans to winterize existing parks; however, on a more optimistic note, some new, larger park developments may include the development of ice rinks. 


\section{Summary of Park Assessment Not present $\square$ Poor $\square$ Mediocre $\square$ Good}

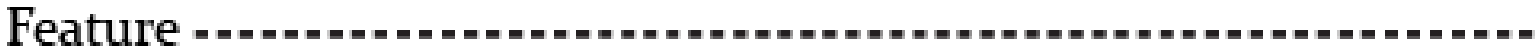 \\ Dedicated trails (walking/hiking) 0 Dedicated trails (snowshoeing/skiing) Surface is uneven/cracked in some areas, and in need of minor repairs. Trails are protected in some

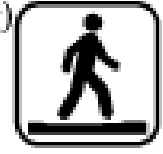 Curling rink Sledding areas by vegetation. Sidewalks Ice Rink}

\section{Amenity \\ Access points \\ Not all access points are clearly marked with signage. Most access points are visible.}

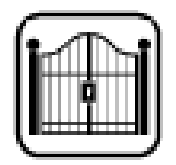

0 Change rooms

Rental equipment/facilities

6 Yegetation/Landscaping Trees have been planted that provide some protection from cooling winds. Some evergreens present.

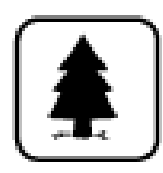

1 Bathrooms

One bathroom in the park is locked behind a gate and inaccessible.

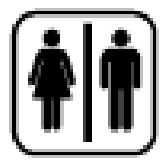

\section{Winter Maintenance}

Snow removal

Trails have been cleared of snow and are easy to travel on.

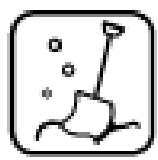

\section{Ice removal}

Trails have been salted and cleared of ice; however, some large ice patches still remain.

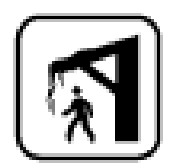

6 Snow storage

Snow stored in medium-sized piles throughout the park, usually on the side or at the end of a trail Some snow mounds are used as play spaces.

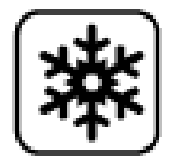

4 Signs/updates on conditions Signage regarding safety conditions of water bodies, trails, etc. is sporadically provided.

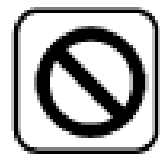

Figure 3: summary of assessment of Smythe Park 
Even more significant for the use of the park by pedestrians was the lack of dedicated sidewalks. From the western entrance off Scarlett Road to the end of Black Creek Trail, there were no dedicated sidewalks for pedestrians. In order to enter the park by foot from Scarlett Road, pedestrians must share the road with vehicles entering and exiting the park, as this entrance was the only vehicular access point. The separation of pedestrian and vehicular traffic is a significant safety feature year-round, as it prevents collisions between vehicles and pedestrians. In the winter months, this separation is even more important in light of the presence of water, slush and ice. During the winter specifically, given the risk of vehicles sliding on ice and losing control, the separation of pedestrians and vehicular traffic is an important measure to avoid pedestrian-vehicle collisions. Moreover, this separation can prevent pedestrians from being sprayed with cold slush/water as cars pass through large puddles of slush and water. At Smythe Park, however, pedestrians run the risk of being

Figure 4: looking east on the main formal trail

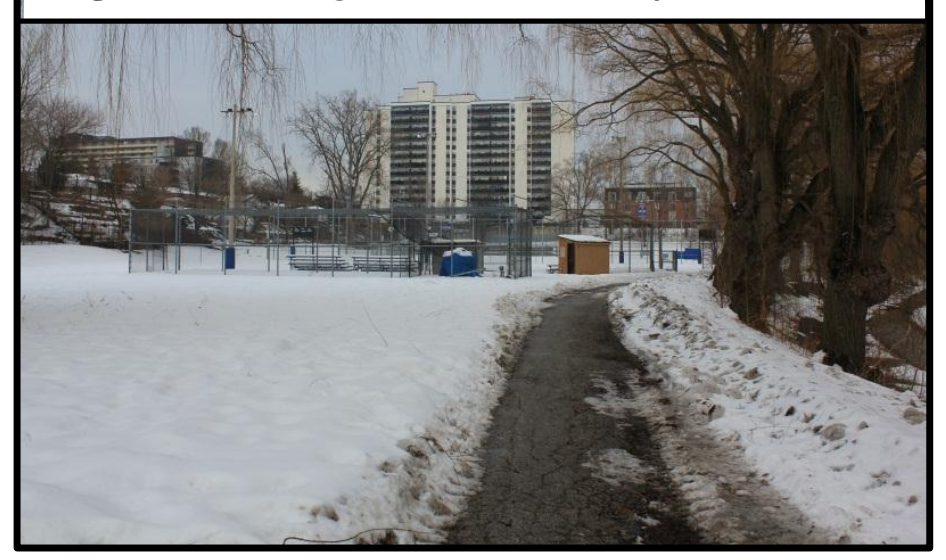
sprayed by slush from the puddles as cars pass, or, much worse, being hit by a car, as there is no separation of pedestrian and vehicular traffic.

Dedicated walking trails began in the central portion of the park, south and north of the pedestrian bridge, and meandered through the eastern portion of the park, terminating at the

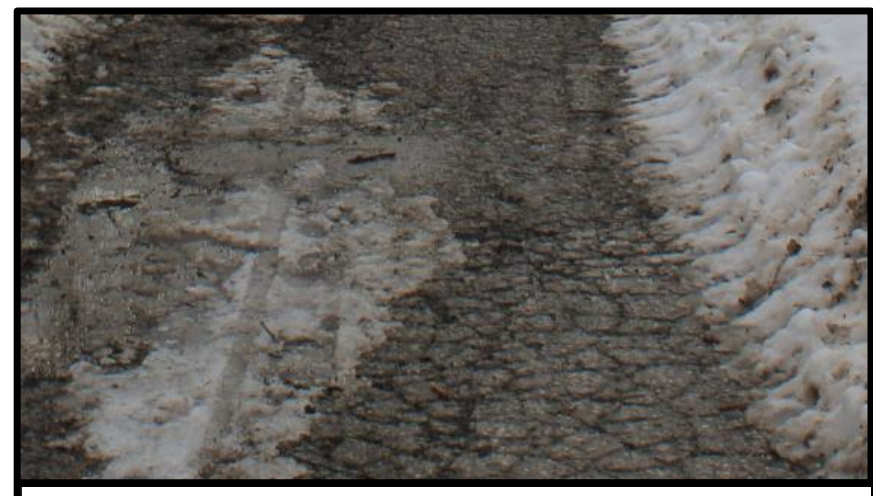

Figure 5a: an example of the cracking in the trails

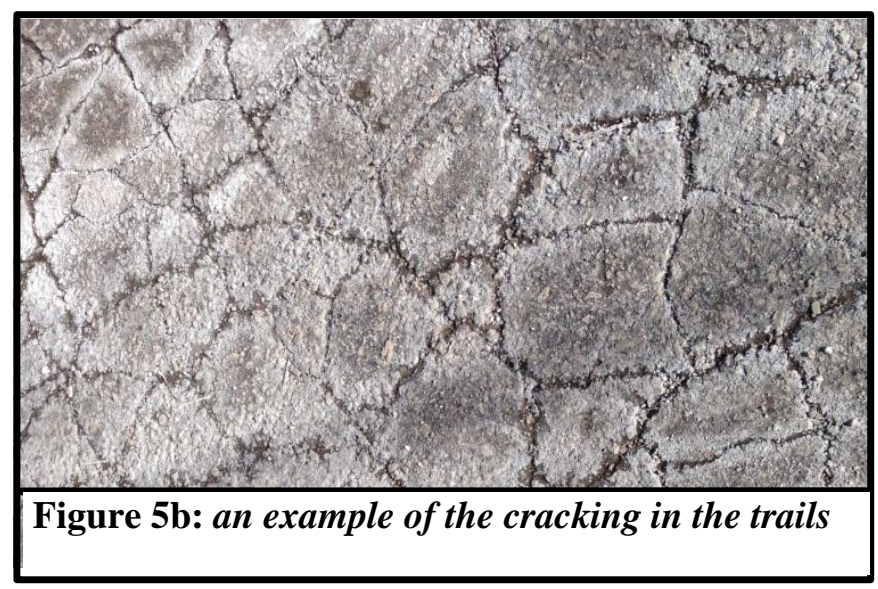


access points from Jane Street in Quadrant 3. The main trail running in an east/west direction, north of the Humber tributary, terminated at the pedestrian bridge (Figure 4); west of this pedestrian bridge, the trail became informal. The trails throughout the park were generally in decent condition, although some cracks and uneven surfaces were observed (Figure 5a \& 5b). Parts of the trail, particularly in Quadrant 2 near the pedestrian bridge, were heavily covered by fallen tree debris from surrounding vegetation, making it difficult to navigate the trail. The presence of walking trails has been cited as one of the most important park characteristics for engagement in physical activity. Although Smythe Park did have walking trails present, the quality and winter maintenance of the trails is equally, if not even more, important when considering their use for physical activity: the mere presence of walking trails will not encourage use if they are covered in snow or ice and difficult to navigate. The quality of maintenance of such trails will be explored in section 3.1 .3 of this study.

In addition to the formal walking trails in the park, a number of informal trails were observed north of the Humber Tributary and west of the pedestrian bridge, as well as connecting the meandering paved trails in the most easterly portion (Quadrant 3) of the park (Figure 6).

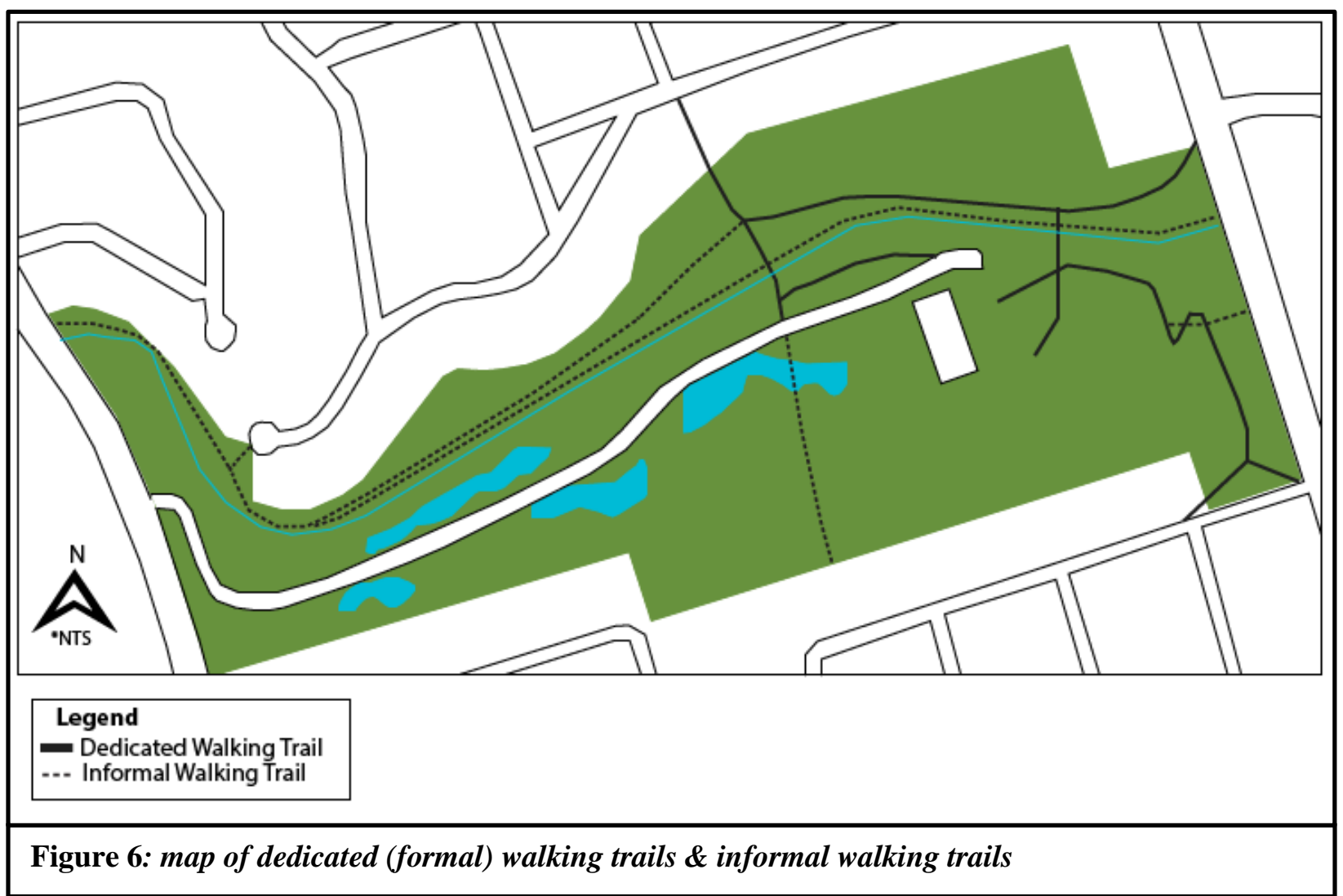


These informal trails were indicated by the presence of packed-down snow, as well as footprints (Figure 7a \& b). Part of the informal trail extending east from Scarlett Road in Quadrant 1 was elevated and separated from the water by a fence. The trail appeared to have been partially shovelled as well (Figure 7c). Other informal walking trails were evident on the paved floodplains beside the Humber River tributary. Only a few set of footprints were observed in these areas, and the snow was not packed, which suggests less frequent use of these trails compared to the other informal trails observed in the park. These were inaccessible and informal trails, and as such had not been cleared of snow; however, in areas where the water had iced over, it was very difficult to determine where the concrete trail ended and the ice commenced, which could pose a safety concern (Figure 7d).
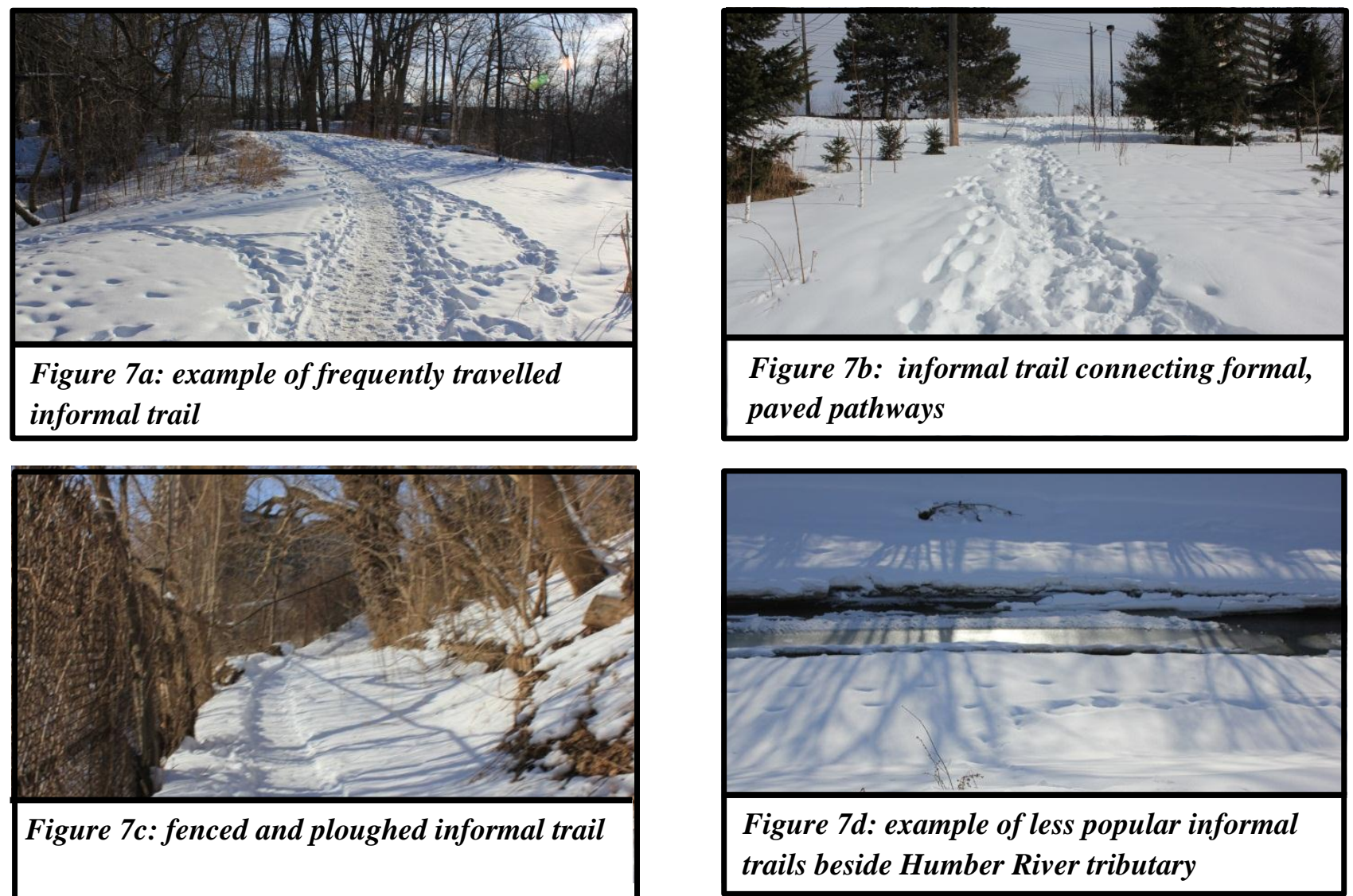

\subsubsection{Amenities}

A total of seven access points were observed at the park, four of which appeared to be formally planned access points. Three of these four access points were marked with City of Toronto signage, indicating the name and address of the park, and municipal codes associated 
with park use. These were located at the Scarlett Road vehicular entrance, the pedestrian access point from Black Creek Boulevard, and the northern pedestrian access point from Jane Street. The access point at Scarlett Road also had a sign indicating the hours of the park; however, this sign was very small and barely visible, especially for those travelling northbound on Scarlett Road and turning right into the park. The southern access point from Jane Street was not marked with signage, as this access point is actually considered part of Haney Park, located at the northwest corner of Haney Avenue and Jane Street. As such, this access point was marked by Haney Park signage. As previous research has suggested, park access is a key factor in influencing the use of parks. Smythe Park could be easily accessed by various modes (bike, car, or foot) from the west side, while access on the east side was restricted to only pedestrian and active transportation. The access points at Smythe Park were visible and easily accessible, with no obvious obstructions for people wishing to use the park. Moreover, there was no fee to use the park, which increases accessibility for people of all income backgrounds

Three 'informal' access points were noted: at Scarlett Road, north of the vehicular entrance, at the west end of Black Creek Boulevard, and at Haney Avenue. These entrances were not marked with any signage. The Black Creek Boulevard access point was hidden from view, unless one used the fenced informal trail in Quadrant 1. This access point had not been cleared of snow, and thus was not as accessible as other access points. The Haney Avenue access point, as well as the formal Black Creek Boulevard access point, appeared to be used primarily as an entry/exit points for those cutting across Smythe Park as a shortcut route.

These access points all connected with the formal trail system in Smythe Park. The lining of such trails with coniferous vegetation is cited as a means of

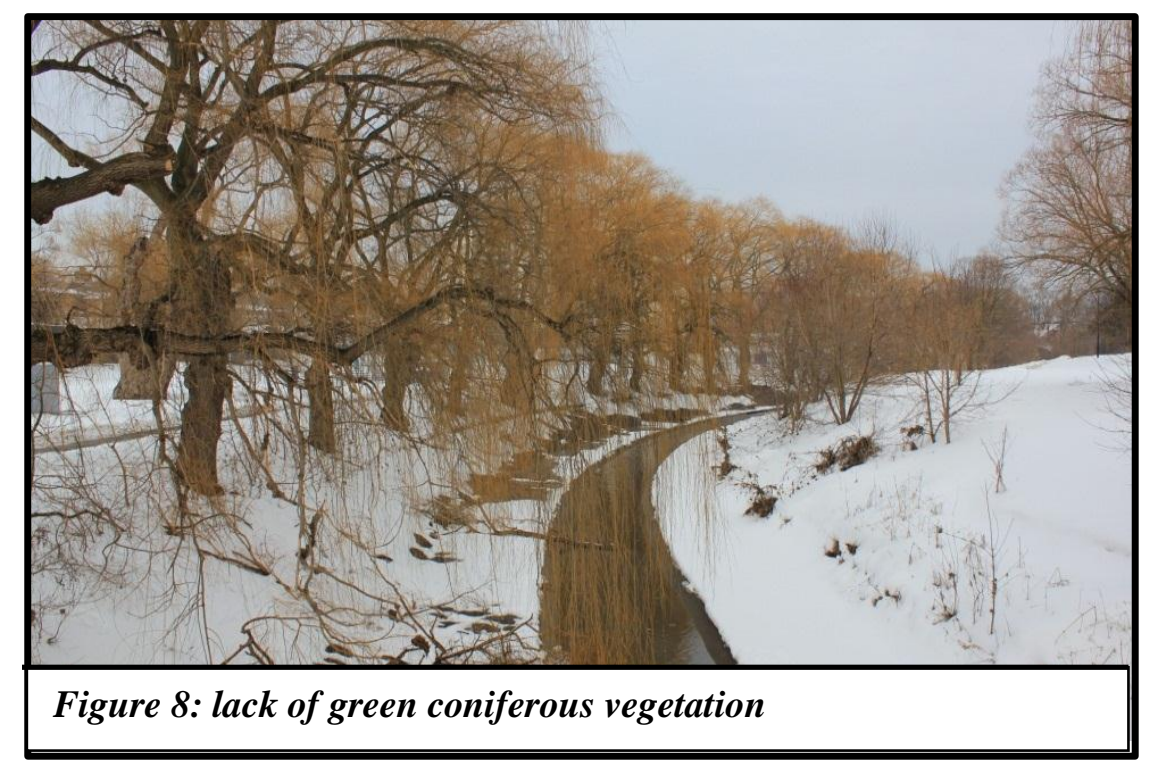


protecting pedestrians from cooling winds (Pressman, 1996; Pressman, 1988; Coleman, 2008), as well as adding bold colors to an otherwise dull and grey winter landscape (Pressman, 1996). Smythe Park was heavily vegetated with large trees. Near the Humber Tributary, which is arguably the most picturesque area of the park, there was dense vegetation lining the trails; however, these trees were bare and lacked any greenery (Figure 8). As such, they did little to lessen the impact of strong winds, nor add any vibrancy to the park. In Quadrant 3, however, the presence of green coniferous evergreens was noted, suggesting that some winter landscaping has been considered by park planners. These large trees were sporadically planted throughout the entire area of Quadrant 3, and a number of smaller, younger evergreens were also present in the area. Although their sporadic planting did not allow for much protection from cooling winds, the trees did add color to the park, and made that area a lot more lively and exciting compared to the dead, barren trees in Quadrant 2 (Figure 9).

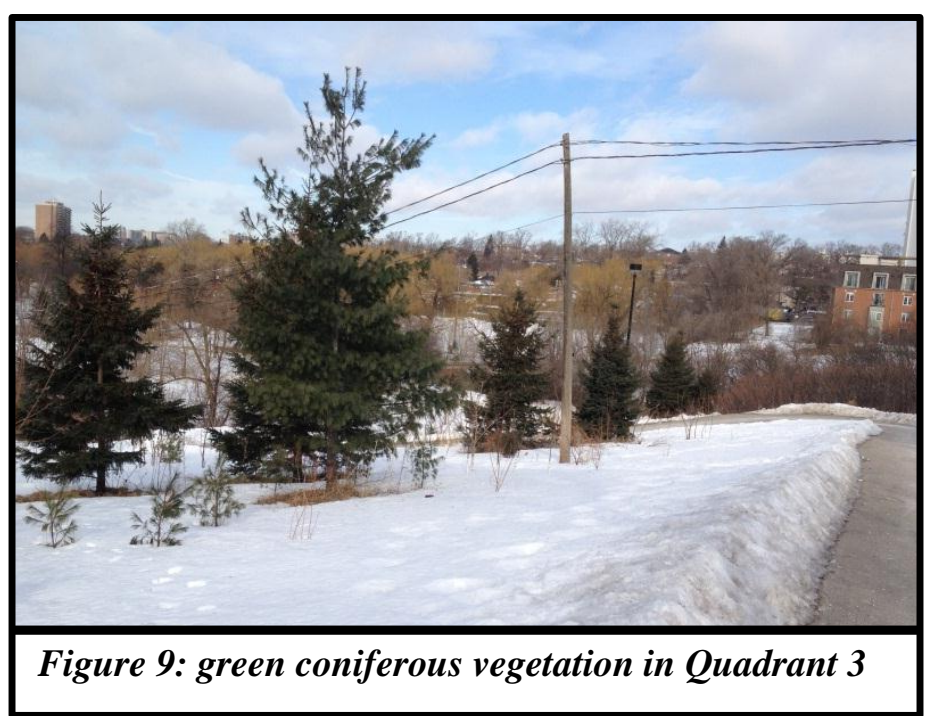
Also absent from the park were bathrooms, change rooms, and facilities for the rental of equipment such as snowshoes or cross-country skis. Although there was one bathroom facility located in the center of the park, it was situated within the swimming pool complex, behind a locked fence. As such, the bathrooms were inaccessible to the general public in the winter. Consistent with the findings from Simic's (2007) National Park study, two of the survey respondents in this study suggested that the park would benefit from the addition of washrooms, and that this would encourage them to increase their use of the park for physical activity. One respondent remarked that they "cannot stay long at the park because there are no washrooms". As mentioned earlier, it is not only the presence of physical activity programming that encourages physical activity, but also supporting amenities, such as washrooms and rental facilities, that increases the likelihood of a park being used for physical activity (Kacynski et al., 
2008). In order to encourage people to not only visit the park, but stay in the park and engage in activity there, the addition of supporting amenities, particularly washrooms, is a top priority.

\subsubsection{Winter Maintenance}

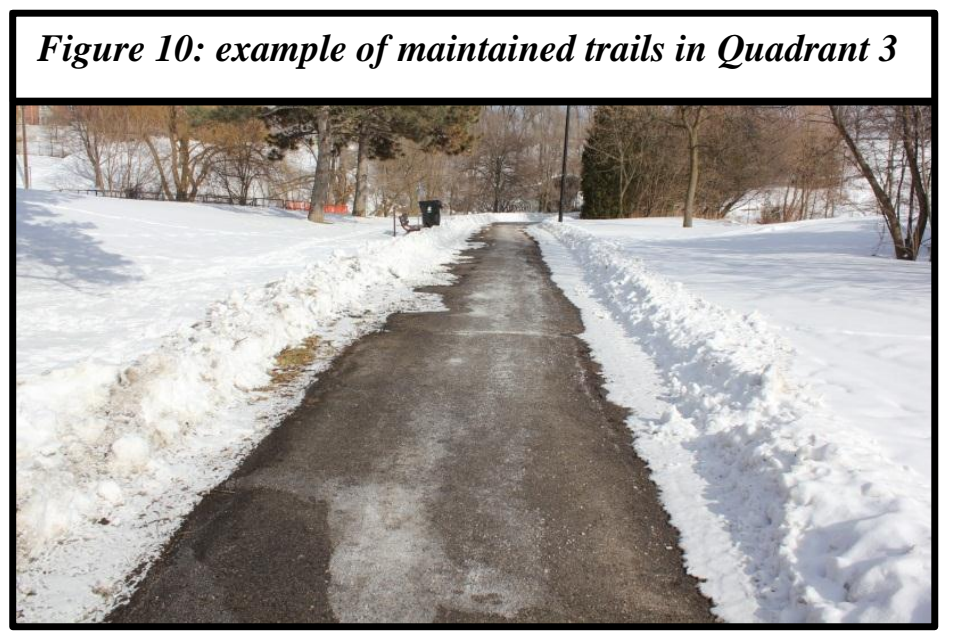

Smythe Park showed evidence of being maintained by City staff during the winter months; however, the quality of the winter maintenance varied between visits. Overall, snow removal at the park was very consistent, and snow removal received the highest rating of all categories in the assessment criteria. All dedicated trails and roads were completely cleared of snow on all visits to the park (Figure 10), and even some of the informal trails - particularly the fenced trail in Quadrant 1 - appeared to be partially shovelled in order to ease pedestrian movement. The literature has suggested that the general maintenance of park features is a critical determinant in whether or not people use the parks for physical activity.

Moreover, positive perceptions of a park's quality are associated with increased parkbased physical activity (Bai et al., 2013). In particular, the winter maintenance of trails has been cited as a key requirement for the use of parks during the winter months (Simic, 2007; Boivin, 1988). This sentiment was noted in one of the informal interviews conducted for this survey. When asked about her use of the park for physical activity, the female respondent remarked that she could resume using the park for her walking routine because "the trails are finally ploughed". What this and the

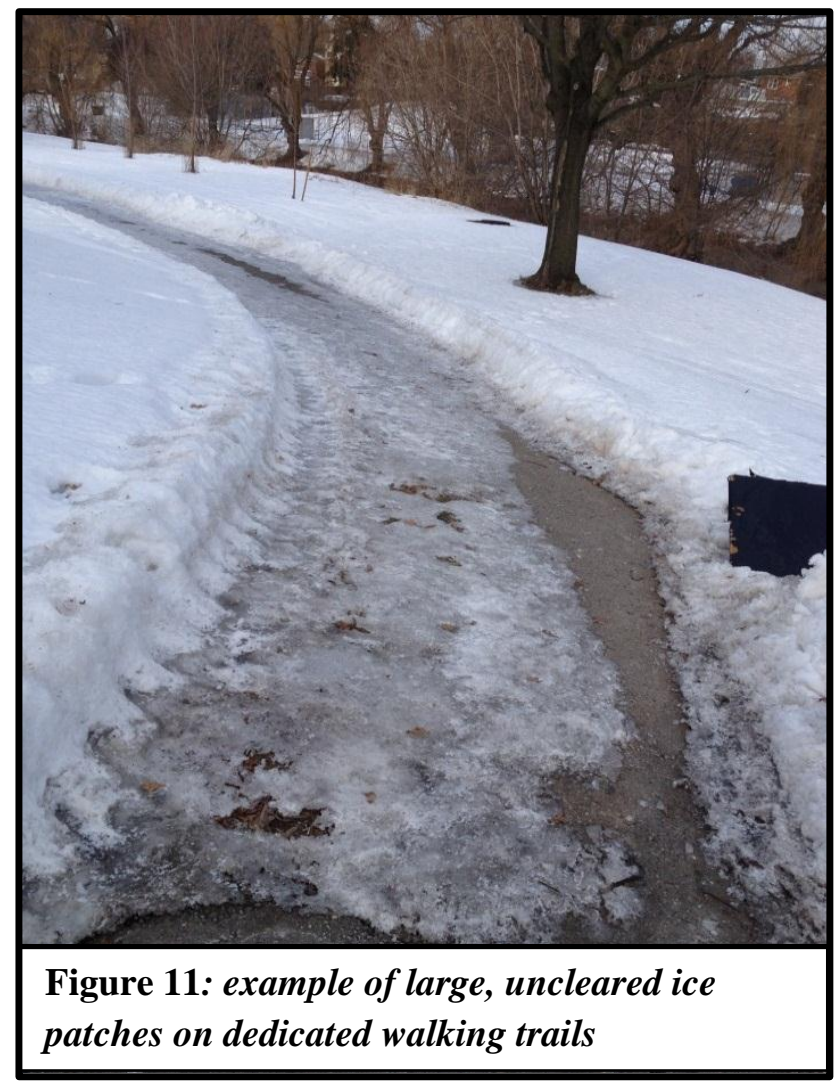


findings from other studies suggest is that the maintaining trails can have a positive influence on people's choice to use parks for physical activity purposes.

On the contrary, a lack of maintenance of park features can have a negative effect on the use of the park for physical activity. In addition to snow removal, the park had been cleared of ice as well; however, ice removal was much more inconsistent than snow removal. It was this inconsistency that lent this item to have only a mediocre rating in the site assessment. During the first three visits, the park was free of any ice on the trails, pedestrian bridge, and road. Ice salt was visible when walking along the trails. This combination of snow and ice removal made the trails easily navigable and enjoyable to walk on. However, after a week of temperatures alternating above and below freezing levels in Toronto, and the subsequent melting and refreezing of snow, large ice patches were observed in the park on the final site visit (Figure 11). Although it appeared that effort had been made to clear the ice - for example, ice salt could be observed in the vicinity of the ice patches - the large ice patches remained. The presence of this ice made it very difficult and dangerous to navigate the trails; one user was even observed slipping and falling on the ice. Supporting this observation, one respondent noted that there was too much ice, which meant that he could not "run on the trails without fear of slipping". Moreover, one female who was approached to participate in the study refused to do so, stating that the only purpose for her coming to the park was to feed the ducks, because "everything is just frozen and covered in ice". Such findings are consistent with Boivin's (1988) study, wherein a number of respondents voiced their displeasure with the dangerous walking conditions on the trails. Ice on the trails is a significant safety concern, especially when considering the use of trails for walking or highspeed running, and should be a top priority for park planners

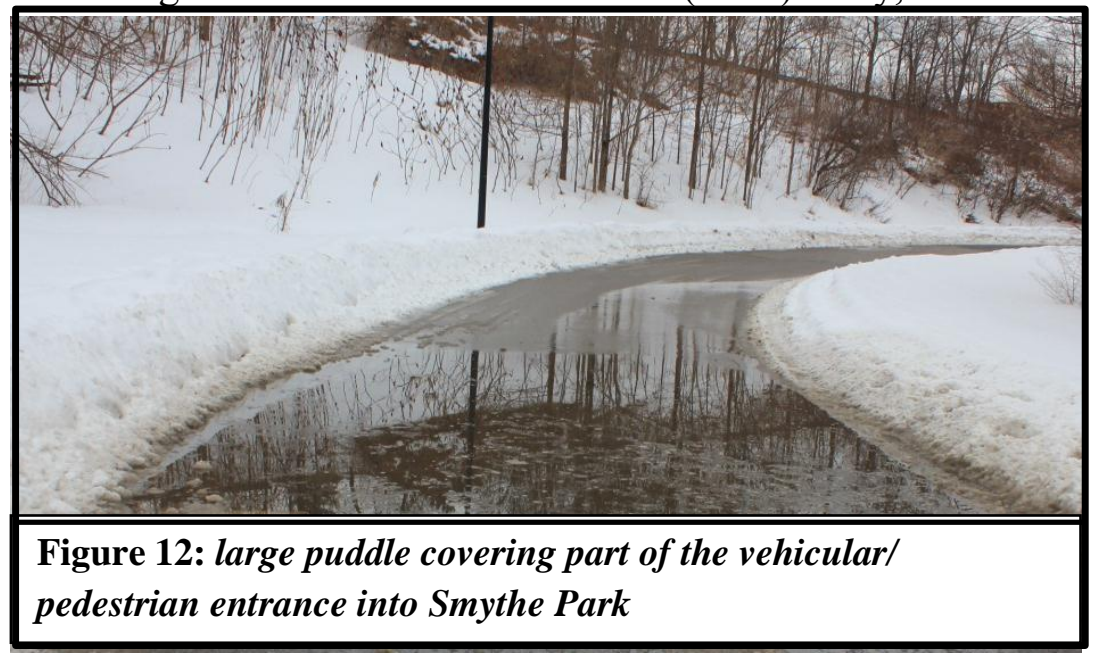
and maintenance staff. 
The excess snow and ice that was cleared in the park was stored in medium-sized mounds on the perimeter of the trails, as well as in unused parts of the parking lot. Some of these mounds were observed to be used by children as play areas. While capitalizing on underutilized space to store snow - and having the mounds serve an alternate purpose of play space - is cited as good winter design practice, this item received a mediocre rating. The reason for this was the fact that on subsequent visits, when the weather was significantly warmer than the initial visit, large puddles were observed on the trails and roads (Figure 12). Such an observation suggests that the storage of the excess snow was inadequate; the mounds were too large, and they were not positioned in a proper location so as to prevent flooding. It is important that this snow and ice is properly stored, as the flooding of sidewalks and pathways can create barriers to pedestrian access, and, for those who choose to walk through the water, an uncomfortable experience.

The final assessment item, also importantly related to safety, was the presence of signs and updates regarding surface conditions, both of the trails and the water bodies throughout the

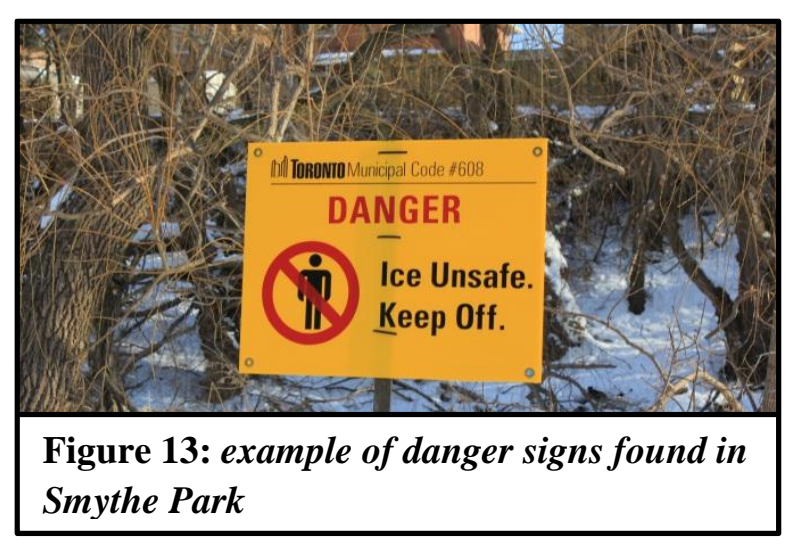
park. Two types of signs were observed in the park. The first type of sign was a yellow danger sign, warning users to keep off the ice that has formed in the water bodies (Figure 13). These were primarily observed in Quadrant 2, along the main road into the park. The second type of sign was a white sign indicating that one of the two pedestrian bridges was closed. This sign was observed on the eastern pedestrian bridge in Quadrant 3, and was accompanied by a gate blocking access to the bridge. The closure of the pedestrian bridge, and associated signage, suggests that those maintaining the park assessed it for pedestrian safety concerns; winter safety at Smythe Park has been considered. However, although the main roadway into the park was heavily populated with signage, there was little to no signage in Quadrant 3 or along the informal pathways in Quadrant 1, although these areas could benefit from signage. For example, along the informal pathway leading to the fenced trail in Quadrant 1, there was a steep and slippery slope towards the water; however, there was no signage to indicate so. In areas in Quadrant 3 where the Humber Tributary had frozen over, there was no signage to deter people from keeping away 
from the icy water; as noted earlier, however, footprints were observed beside the Tributary, suggesting that people were walking in these potentially dangerous areas. Although none of the survey respondents recommended more signage at the park, other more comprehensive studies (Simic, 2007) have suggested that users desire better maps and signage in their national parks. Signage indicating potential dangers, as well locating informal but well-used pathways (i.e. wayfinding), could contribute to a safer and better used park.

\subsubsection{Other Concerns}

Although the main focus of the analysis and surveys was winter maintenance and programming of the park, discussion with park users also pointed to other important concerns, namely that of safety. When speaking to the one female respondent for this study, she voiced her concerns about the safety of the park, as one day when she was partaking in her walking routine, she was followed. She noted that she had to cut her walk short, exiting the park from one of the access points that lead into a heavily populated neighbourhood. She also observed that she often saw many cars coming in and staying at the park, but never saw very many people walking around. She questioned why this was so, suggesting that "maybe they're dealing drugs". The respondent said that in order to increase her use of the park for physical activity, park planners would definitely have to improve the park's safety, perhaps through more lighting. When assessing the park, it was noted that the informal trails that are popularly used had no lighting; lighting was mainly restricted to the roadway and parking lot in the park. As such, although not directly related to encouraging physical activity, improving the lighting at the park could encourage greater use of the park. 


\subsection{Park Use}

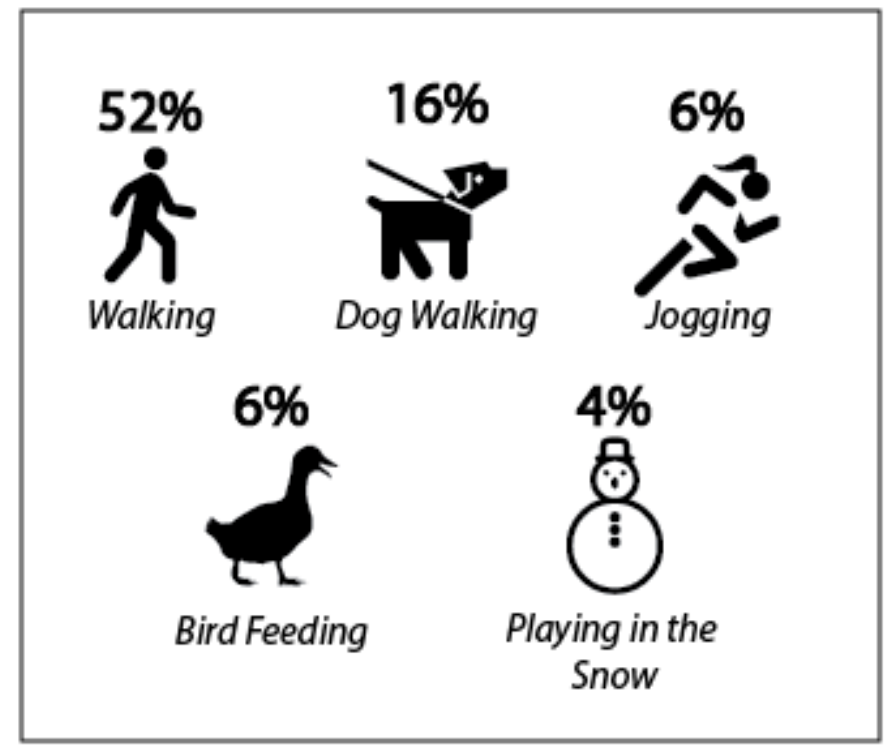

Figure 14: distribution of uses observed at Smythe Park

An analysis of the quality and conditions of Smythe Park suggests that it lacked any winter-specific features, and had little to no supporting amenities, although it did show evidence of some winter maintenance. In spite of this, over the course of the four days of observation, a total of 50 people were observed using the park. The distribution of observed uses can be found in Figure 14. Although the study was on a much smaller scale than Boivin's (1988) study of High Park, results were very similar in that walking, dog walking, and jogging were the most common activities in the park.

$52 \%$ of the users were observed walking in the park. The majority of these walkers were wearing active wear (running shoes, tights, sweatbands), and were not carrying knapsacks, grocery bags, etc. They appeared to be engaging in walking as a form of physical activity, and were observed walking along the paved trail on the southern side of the park, as well as the informal walking trail north of the tributary and west of the pedestrian bridge. Two walkers on separate days were observed repeatedly walking from one end of the parking lot to the other end, one of which was observed rotating his arms in large circles while walking. This same user was observed changing into running shoes and a running jacket in the parking lot before beginning his walk. Such an observation is connected to the assessment of the park, in that Smythe Park lacked any bathrooms or change rooms. Providing such spaces, especially if they contain lockers, 
can motivate people living in the vicinity of the park to not only walk to the park, but to also engage in physical activity while there, as they have a space to store their heavy winter jackets and other accessories that may not be ideal to wear while working out. By providing such facilities, those living within walking distance may not feel the necessity to drive their car to the park, as they have an alternate space to store their excess clothing and accessories.

Three of the observed walkers in Smythe Park were children wearing knapsacks. They were walking in an easterly direction, likely towards the school located east of Jane Street. Besides these children, most walkers that were not wearing active wear were observed cutting across the park, from the access point at Black Creek Boulevard to the access point at Haney Avenue.

An additional $32 \%$ of the park users were observed walking their dogs. These users generally kept to the informal walking trails on the northern side of the park, west of the pedestrian bridge. Only $6 \%$ of the users were observed jogging. Three users $(6 \%)$ were observed playing in one of the ploughed snow mounds; two of these users were young children, and one was a male adult. Two people were observed feeding ducks.

The observations of park use suggest that it is more active (walking, jogging) rather than passive (sitting, standing, feeding ducks, reading) activities that people partake in during the winter at Smythe Park. Although there were a number of people observed engaging in physical activity in Smythe Park, of the four respondents interviewed, the two which indicated they exercised regularly (3-5 times a week) noted that they did not use the park as part of their physical activity regime, although they did exercise outside regularly. Moreover, they both indicated that the park conditions do in fact influence their decision not to use the park for physical activity; primarily, the lack of bathrooms and the lack of ice removal on the trails. Such an observation provides a tangible example of what has been demonstrated in the literature: park conditions do affect park use, and regular maintenance and programming, especially in the winter, is required in order to increase engagement in physical activity. 


\section{Chapter 5: Recommendations \& Best Practice}

\subsection{Smythe Park Recommendations}

What the assessment of Smythe Park suggests is that, although the park is used for phsyical activity (primarily walking) to some extent, the park lacks the essential features, amenities, and maintenance activities associated with high levels of physical activity, especially from a seasonal perspective. There are both small- and large-scale modifications that should be made to Smythe Park to encourage increased winter physical activity levels in the low-income neighborhood.

Some minor, less expensive modifications that could be made to Smythe Park include:

- Planting of coniferous vegetation to add color to the space as well as protect pedestrians from cooling winds. These should primarily be planted along the trails;

- Better maintenance of trails in relation to ice removal. Main trails should be cleared of snow and ice, particularly after a storm or periods of fluctuating temperatures that cause snow to melt and refreeze into ice patches, especially in light of the fact that the most common park uses are walking and jogging;

- Existing bathrooms should be open to the public year-round. They should be heated and lockers should be provided; and

- Winter programming in the form of snowshoeing trails, skating pathways, or ice rinks can be created by from the existing natural landscape and built form. For example, there are a number of small ponds in Smythe Park that could be converted into ice rinks. Snow can be packed on the informal trails to be utilized as walking or cross-country trails. An existing walkway can be flooded to create a skating pathway (Coleman, 2010).

A more costly but essential modiciation that should be made is the creation of paved sidewalks separted from vehicular traffic. As the park currently exists, pedestrians wishing to enter the park from the west are forced to either share the road with incoming and outgoing vehicles, or travel on the informal trails. A pathway that is separate from the road and properly maintained can provide a safer entry into the park, as pedestrians will be better protected from slush spray and from collisions with cars. More costly programming, such as a manmade ice rink with boards to play hockey, could also be added to the park; however, as mentioned, an equally 
effective and less expensive approach is to convert the existing natural landscape into physical activity facilities. Overall, these modications can create a safer (maintenance of trails, signage), more comfortable (protective vegetation, heating in bathrooms) and more exciting (winter programming) environment that, together, can encourage people to not only visit the park, but to stay at the park and engage in some form of physical activity.

\subsection{City of Toronto Parks Recommendations}

Smythe Park is only one of over 1600 parks in Toronto (City of Toronto, 2014b). Toronto's parks have varying degrees of winter programming and maintenance, and differ in terms of size and neighborhood characteristics. For example, in contrast to Smythe Park, High Park is a 161 hectare park located in a high-income neighborhood, with $44 \%$ of family households and $29 \%$ of private households having an income of over $\$ 100,000$ (City of Toronto, 2014b). The park has a hockey rink, cross-country trails, bathrooms, and designated "discovery walk" trails. Although all parks could benefit from the recommendations listed for Smythe Park, it may not be feasible to achieve the level of winterization present at High Park, given city budgets and staffing. As such, the City's top priority should be parks in low-income neighborhoods. By focusing on improving the winter programming and maintenance of parks in low-income neighborhoods, the City can help to reduce the disparities in park quality and disparities in physical activity levels, consequntially improving health equity between highincome and low-income neighborhoods.

One way of encouraging the consideration of winter in park design is by incorporating policies in the form of design guidelines and zoning by-laws (Pressman, 1996). Another option is to use Section 37, whereby developers can receive exemptions from height and density requirements for their buildings in exchange for a service or facility deemed to be a "public good". In this instance, the public good could be, for example, an ice rink or cross-country skiing trail in a neighbourhood park (Pressman, 1996). Overall, when planning to winterize specific parks, the City of Toronto Parks department must consider year-round usability of parks (Pressman, 1996). Planners need to consider summer and winter use of the park, and ensure that programming does not ignore the interests of one season to accommodate another; the programming must have multi-functional uses. 


\subsection{IceSkatePark - Mississauga, Ontario}

Some of the important considerations and recommendations mentioned above have been exemplified in a potential project in the City of Mississauga, Ontario, although the project is more intensive and costly than some of the simpler recommendations mentioned for Smythe Park. A non-profit group, Ice Park, has developed a plan for a 8-hectare, "\$60 million winter facility that would include a 1.6-kilometre ice trail modelled after the Rideau Canal, a worldclass speedskating oval, hockey rinks, curling, a state-of-the-art toboggan run and more" (Grewal, 2012, n.p.). Adopting the idea that open spaces should be multi-functional and usable year-round, the spaces in the park would be converted to roller-blading trails, beach volleyball courts, and an open-air pool during the summer months. Even more significant for this discussion is the fact that "the intent of IceSkatePark is to inspire as many physically inactive people as possible to make visiting IceSkatePark a healthy habit. For this to happen, admission fees must be low enough to attract people of almost all economic means" (IcePark Group Inc., 2014, n.p.). The most attractive aspect of this project is the fact that it is being proposed as a means of improving health equity amongst various economic groups and increasing winter physical activity levels, by providing a state-of-the-art facility at a very low cost. Whether or not the park will actually be built is unknown; however, the value of this project is in the way it has embraced the idea of a "livable winter city" and has incorporated the need to build winter physical activity facilities, as well as make them accessible to people of all economic backgrounds, so as to improve overall engagement in physical activity. The concepts employed in the theoretical design of this park are ones that should be carried through to future park planning and design. 


\section{Chapter 6: Conclusion \& Future Research}

The winterization of parks in low-income neighbourhoods - in the form of providing features and amenities related to winter activities, and winter maintenance - is a largely understudied topic. However, it is an extremely important topic in light of findings that suggest low-income residents have lower levels of physical activity and reduced access to indoor recreational facilities, in conjunction with findings that suggest physical activity levels in general are lower during the winter. This study has sought to contribute to the small set of existing literature on the topic by assessing the presence and conditions of winter facilities, as well was the level of winter maintenance in a park in a low-income neighbourhood. The findings suggest that there is significant room for improvement in the Toronto's Smythe Park. The park lacked any form of winter features and supporting amenities, and although there was evidence that it had been maintained - snow had been removed from the trails, signs about winter conditions were present, and ice salt had been laid - there were instances where this maintenance was inconsistent. Survey respondents acknowledged this lack of maintenance as affecting if and how they used the parks for physical activity, with the ploughing of snow encouraging their use of the trails for walking, and the presence of ice and lack of ice removal discouraging them from running on the trails. The observations in this studied provided a tangible example of what has been demonstrated in the literature: park conditions do affect park use, and regular maintenance and programming, especially in the winter, is required in order to increase engagement in physical activity.

Although these findings are not generalizable for all other parks in Toronto, the case study provides important insights into the importance of winter maintenance and winter park programming to increase physical activity levels. At the very least, park planners should ensure consistent snow and ice removal on the trails in the park, as the presence and quality of walking trails is vital for encouraging physical activity, and especially in light of the fact that the most common park uses in this and other studies (Boivin, 1988) are walking and jogging on trails. Of all supporting amenities, the presence of bathrooms is particularly important for encouraging people to stay in a park. Where feasible, the addition of some form of winter feature utilizing the 
natural landscape, for example an ice rink, can also be key in improving winter physical activity levels.

Despite these findings, more work will need to be done in order to fully understand the effect that winterization has on the use of parks for physical activity, specifically in low-income communities. Future research should focus on assessing a number of different parks in Toronto, in order to gauge the various degrees of winterization that exists, and to identify key areas needing improvement. Moreover, this study only collected a small survey sample, and respondents ranged significantly in their economic backgrounds. Future studies should survey/interview a larger number of people, with a focus on collecting data from low-income residents, in order to focus specifically on the needs of, and issues raised by, low-income citizens. By doing so, studies can better inform the park planning profession on how to design parks so as to reduce the health equity gap between low-income and high-income neighborhoods, and encourage their use year-round 


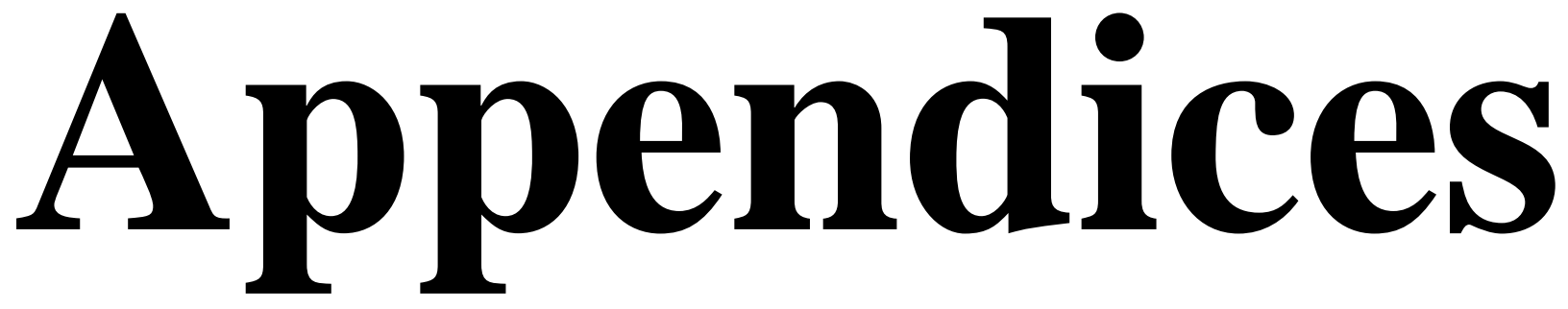




\section{Appendix A}

Assessment criteria used to analyze Smythe Park, based off the PARA tool

Date:

Weather Conditions:

Hours of Operation: to Start time:

Stop time:
Signage (hours): $\mathrm{Y}$ or $\mathrm{N}$

Maps: Y or $\mathrm{N}$
Signage (rules): $\mathrm{Y}$ or $\mathrm{N}$

Information Boards: $\mathrm{Y}$ or $\mathrm{N}$

Rating: $\mathbf{0}=$ Not Present $\mathbf{1}=$ Poor $\quad \mathbf{2}=$ Mediocre $\mathbf{3}=$ Good

\begin{tabular}{|c|c|c|c|c|}
\hline Feature & \multicolumn{4}{|c|}{ Rating } \\
\hline Dedicated (formal) trails (snowshoeing/cross-country skiing) & 0 & 1 & 2 & 3 \\
\hline Dedicated (formal) trails (walking/hiking) & 0 & 1 & 2 & 3 \\
\hline Ice rink (skating/hockey) & 0 & 1 & 2 & 3 \\
\hline Curling Rink & 0 & 1 & 2 & 3 \\
\hline Sledding & 0 & 1 & 2 & 3 \\
\hline Sidewalks & 0 & 1 & 2 & 3 \\
\hline Other: & 0 & 1 & 2 & 3 \\
\hline Other: & 0 & 1 & 2 & 3 \\
\hline Amenity & \multicolumn{4}{|c|}{ Rating } \\
\hline Access points & 0 & 1 & 2 & 3 \\
\hline Bathrooms & 0 & 1 & 2 & 3 \\
\hline Change Rooms & 0 & 1 & 2 & 3 \\
\hline Vegetation/Landscaping & 0 & 1 & 2 & 3 \\
\hline Rental Equipment Facilities & 0 & 1 & 2 & 3 \\
\hline Shelters & 0 & 1 & 2 & 3 \\
\hline Other: & 0 & 1 & 2 & 3 \\
\hline Other: & 0 & 1 & 2 & 3 \\
\hline Winterization/ Winter Maintenance & \multicolumn{4}{|c|}{ Rating } \\
\hline Ice removal & 0 & 1 & 2 & 3 \\
\hline Snow removal & 0 & 1 & 2 & 3 \\
\hline Snow storage & 0 & 1 & 2 & 3 \\
\hline Signs/Updates on Surface Conditions & 0 & 1 & 2 & 3 \\
\hline
\end{tabular}

\section{Comments:}




\section{Appendix B}

\section{Operational definitions for assessment tool}

\begin{tabular}{|c|c|c|c|}
\hline Feature & Poor & Mediocre & Good \\
\hline $\begin{array}{l}\text { Dedicated (formal) } \\
\text { Trails }\end{array}$ & $\begin{array}{l}\text { Surface is unsafe in } \\
\text { many places; a lot of } \\
\text { debris; no signage about } \\
\text { appropriate use; trails } \\
\text { are not protected by } \\
\text { natural vegetation to } \\
\text { protect from cooling } \\
\text { winds }\end{array}$ & $\begin{array}{c}\text { Surface is in places } \\
\text { uneven, or in need of } \\
\text { minor repair; may be a } \\
\text { few hazards or avoidable } \\
\text { debris; trails are } \\
\text { protected in some areas } \\
\text { by vegetation }\end{array}$ & $\begin{array}{l}\text { Surface is smooth, without } \\
\text { unmarked hazards or debris; } \\
\text { has signage re: appropriate } \\
\text { use; trails are protected by } \\
\text { vegetation }\end{array}$ \\
\hline Sledding & $\begin{array}{l}\text { Hills are not marked } \\
\text { with signage; hills are } \\
\text { steep, icy, bumpy and } \\
\text { unsafe to ride down; no } \\
\text { barrier (i.e. hay barrels) } \\
\text { provided to prevent } \\
\text { collisions with trees; hill } \\
\text { ends near a } \\
\text { street/parking lot }\end{array}$ & $\begin{array}{l}\text { Hills are marked with } \\
\text { signage; hills are icy but } \\
\text { generally smooth and } \\
\text { safe to ride down, } \\
\text { although some patches } \\
\text { are bumpy and are a } \\
\text { safety concern }\end{array}$ & $\begin{array}{l}\text { Hills are marked with } \\
\text { signage; hills are well- } \\
\text { maintained and safe to ride } \\
\text { on; barrier is provided to } \\
\text { prevent collisions with trees }\end{array}$ \\
\hline Sidewalks & $\begin{array}{l}\text { Sidewalk has major } \\
\text { damage and needs } \\
\text { repair; almost unusable; } \\
\text { not separated from the } \\
\text { roadway (resulting in } \\
\text { slush spray) }\end{array}$ & $\begin{array}{c}\text { Sidewalk has some } \\
\text { debris, cracks or uneven } \\
\text { surfaces, but otherwise } \\
\text { usable }\end{array}$ & $\begin{array}{l}\text { Sidewalk is smooth; clear of } \\
\text { debris; separated from the } \\
\text { roadway }\end{array}$ \\
\hline Ice Rink & $\begin{array}{l}\text { Surface is unsafe and } \\
\text { uneven, no enclosure of } \\
\text { rink, no signage }\end{array}$ & $\begin{array}{l}\text { Surface is uneven in } \\
\text { some places or in need of } \\
\text { minor repair, rink is } \\
\text { enclosed, enclosure is in } \\
\text { decent condition or in } \\
\text { need of minor repair }\end{array}$ & $\begin{array}{l}\text { Surface is smooth and } \\
\text { maintained, rink is enclosed } \\
\text { with appropriate signage }\end{array}$ \\
\hline Curling Rink & $\begin{array}{l}\text { Surface is unsafe and } \\
\text { uneven, no enclosure of } \\
\text { rink, no signage }\end{array}$ & $\begin{array}{l}\text { Surface is uneven in } \\
\text { some places or in need of } \\
\text { minor repair, rink is } \\
\text { enclosed, enclosure is in } \\
\text { decent condition or in } \\
\text { need of minor repair }\end{array}$ & $\begin{array}{l}\text { Surface is smooth and } \\
\text { maintained, rink is enclosed } \\
\text { with appropriate signage }\end{array}$ \\
\hline Amenity & Poor & Mediocre & Good \\
\hline Access points & $\begin{array}{c}\text { Some appear as } \\
\text { potentially unsafe areas; } \\
\text { unkept; not well marked }\end{array}$ & $\begin{array}{l}\text { Not all access points are } \\
\text { clearly marked; Some } \\
\text { may have trash or piled } \\
\text { up snow }\end{array}$ & $\begin{array}{l}\text { Clearly visible, safe, free of } \\
\text { debris or piled up snow. If } \\
\text { gated, works properly }\end{array}$ \\
\hline Bathrooms & $\begin{array}{l}\text { Locked, or Bathroom is } \\
\text { not clean, not well- }\end{array}$ & $\begin{array}{l}\text { Bathroom is fairly clean; } \\
\text { stocked; and most sinks } \\
\text { and toilets in good }\end{array}$ & $\begin{array}{l}\text { Bathroom is clean, well-lit, } \\
\text { stocked, all plumbing is }\end{array}$ \\
\hline
\end{tabular}




\begin{tabular}{|c|c|c|c|}
\hline & stocked; not heated. & working order; heated. & functioning well, heated. \\
\hline Change Rooms & $\begin{array}{l}\text { Locked; or unclean; } \\
\text { plumbing is almost } \\
\text { unusable; not heated; } \\
\text { appears unsafe/not well- } \\
\text { lit; no gender-separation; } \\
\text { no lockers }\end{array}$ & $\begin{array}{l}\text { Most areas clean; lockers } \\
\text { and/or dressing space } \\
\text { provided (but } \\
\text { inadequate); plumbing } \\
\text { could be improved, but } \\
\text { works; heated. }\end{array}$ & $\begin{array}{l}\text { Clean; well-lit; lockers } \\
\text { and/or dressing space } \\
\text { provided; plumbing works } \\
\text { well; heated. }\end{array}$ \\
\hline Vegetation/Landscaping & $\begin{array}{l}\text { No attempts have been } \\
\text { made at landscaping } \\
\text { outside of grass. No } \\
\text { shelter provided by } \\
\text { vegetation. }\end{array}$ & $\begin{array}{l}\text { Trees have been planted } \\
\text { that provide some } \\
\text { protection from cooling } \\
\text { winds in some open } \\
\text { spaces and on some } \\
\text { walking trails. Some } \\
\text { winter vegetation (e.g. } \\
\text { evergreens) present. }\end{array}$ & $\begin{array}{l}\text { Attractive trees and plants } \\
\text { planted; evergreen trees have } \\
\text { been planted throughout to } \\
\text { provide protection from } \\
\text { cooling winds. }\end{array}$ \\
\hline $\begin{array}{l}\text { Rental Equipment } \\
\text { Facilities }\end{array}$ & $\begin{array}{l}\text { Closed; or difficult to } \\
\text { locate; poor selection of } \\
\text { equipment; high cost }\end{array}$ & $\begin{array}{l}\text { A few designated areas } \\
\text { for rental equipment; } \\
\text { generally easy to locate } \\
\text { but out of the way of } \\
\text { related features; decent } \\
\text { selection of different } \\
\text { equipment and sizes; } \\
\text { fairly priced (but could } \\
\text { be cheaper) }\end{array}$ & $\begin{array}{c}\text { Numerous facilities located } \\
\text { in close proximity to related } \\
\text { features; plentiful selection } \\
\text { of equipment and sizes; very } \\
\text { low-priced or free. }\end{array}$ \\
\hline Shelters & $\begin{array}{l}\text { Structures not intact, so } \\
\text { snow can get in. Not } \\
\text { heated. }\end{array}$ & $\begin{array}{l}\text { Structures are intact and } \\
\text { provide protection from } \\
\text { weather. Not heated. }\end{array}$ & $\begin{array}{c}\text { Structures are in-tact, } \\
\text { provide protection from } \\
\text { weather and are heated and } \\
\text { aesthetically-pleasing. }\end{array}$ \\
\hline $\begin{array}{c}\text { Winter } \\
\text { Maintenance }\end{array}$ & Poor & Mediocre & Good \\
\hline Ice removal & $\begin{array}{c}\text { Sidewalks are } \\
\text { dangerously slippery and } \\
\text { ice has not been } \\
\text { removed. }\end{array}$ & $\begin{array}{l}\text { Sidewalks have been } \\
\text { salted, although some } \\
\text { patches of ice remain. }\end{array}$ & $\begin{array}{l}\text { Sidewalks have been salted } \\
\text { and are cleared of all ice. }\end{array}$ \\
\hline Snow removal & $\begin{array}{l}\text { Sidewalks have not been } \\
\text { cleared of snow \& are } \\
\text { unusable; rinks have not } \\
\text { been cleared of snow } \\
\text { and are unusable; } \\
\text { dedicated trails have not } \\
\text { been cleared of } \\
\text { excessive snow, making } \\
\text { their use difficult }\end{array}$ & $\begin{array}{l}\text { Main sidewalks have } \\
\text { been cleared of most } \\
\text { snow (although some still } \\
\text { remains); rinks are } \\
\text { generally clear of snow } \\
\text { (although the surface } \\
\text { could be smoother and } \\
\text { cleared of excess snow); } \\
\text { dedicated trails generally } \\
\text { cleared of snow }\end{array}$ & $\begin{array}{l}\text { All sidewalks have been } \\
\text { cleared of snow and are } \\
\text { easily walkable; rinks \& trails } \\
\text { have been cleared of all } \\
\text { excess snow and provide a } \\
\text { clear and smooth surface }\end{array}$ \\
\hline Snow storage & $\begin{array}{l}\text { Cleared snow stored in } \\
\text { large mounds that are }\end{array}$ & $\begin{array}{l}\text { Snow stored in medium } \\
\text { sized piles throughout }\end{array}$ & $\begin{array}{l}\text { Snow stored in small piles in } \\
\text { areas where there is adequate }\end{array}$ \\
\hline
\end{tabular}




\begin{tabular}{|c|c|c|c|}
\hline Signs/Updates on & $\begin{array}{c}\text { dangerous or } \\
\text { obstructive for park } \\
\text { users; not enough } \\
\text { adequate storage space } \\
\text { for snow }\end{array}$ & $\begin{array}{c}\text { the park, usually on the } \\
\text { side or at the end of a } \\
\text { trail; some mounds used } \\
\text { as play spaces }\end{array}$ & $\begin{array}{c}\text { room for storage (e.g. large } \\
\text { unused terrace); mounds } \\
\text { utilized as play spaces }\end{array}$ \\
\hline $\begin{array}{c}\text { No signage is provided } \\
\text { regarding safety } \\
\text { conditions of ice, trails, } \\
\text { etc. }\end{array}$ & $\begin{array}{c}\text { Signage regarding safety } \\
\text { conditions of ice, trails } \\
\text { etc. is sporadically } \\
\text { provided; view of the } \\
\text { sign is obstructed or sign } \\
\text { is difficult to locate }\end{array}$ & $\begin{array}{c}\text { Clear signage is provided } \\
\text { regarding conditions of ice, } \\
\text { trails etc.; signage is } \\
\text { provided at key locations } \\
\text { and are easy to locate }\end{array}$ \\
\hline
\end{tabular}




\section{Appendix C \\ Survey employed during site visits}

\section{Ryerson University \\ Consent Agreement}

\section{Winter, Urban Parks, \& Health Equity}

You are being asked to participate in a research study. Before you give your consent to be a volunteer, it is important that you read the following information and ask as many questions as necessary to be sure you understand what you will be asked to do.

This research study is being conducted by myself, Maria Bianchi, at Ryerson University. I am currently a Master of Urban Planning student at the School of Urban and Regional Planning and will be using the results of this survey for my final Major Research Paper. The research is being supervised by Professor Christopher De Sousa, the Faculty Supervisor at Ryerson University's School of Urban and Regional Planning.

I will be studying the connection between the quality of urban parks during the winter and human health in areas in Toronto deemed low-income. I will be recruiting 10 to 15 females or males, over the age of 18, who live in this neighborhood, to participate in this study.

If you agree to participate in this study, you will be asked to complete one survey called "Winter, Urban Parks, and Health Equity." The survey should take 5 - 10 minutes to complete and will include a mix of short answer questions and "multiple choice" style questions.

None of the surveys used in this study are experimental in nature. The only experimental aspect of this study is the gathering of information for the purpose of analysis.

There are very low possible risks associated with your being in this study, although you may feel uncomfortable answering some of the questions related to personal health and income.

Ultimately, the results from this study can contribute to a better understanding of the ways in which parks and their physical characteristics relate to physical activity in urban environments, so as to better improve health equity between low-income and high-income neighborhoods.

The survey you fill out will be confidential. PLEASE DO NOT PUT YOUR NAME ANYWHERE ON THE SURVEY. There will be no way to link you to your responses. All data collected will be transcribed and stored on my own personal computer, in an encrypted file. The hardcopy files will be locked in my personal cabinet in my office. The data will be removed and hardcopy files shredded and thrown out upon submission and approval of my final paper.

You will not be paid to participate in this study.

Participation in this study is voluntary. Your choice of whether or not to participate will not influence your future relations with Ryerson University. If you decide to participate, you are free to withdraw your consent and to stop your participation at any time without penalty or loss of benefits to which you are allowed.

At any particular point in the study, you may refuse to answer any particular question or stop participation altogether. 
Questions about the Study: If you have any questions about the research now, please ask. If you have questions later about the research, you may contact.

Christopher De Sousa: Faculty Supervisor

Ryerson University, School of Urban and Regional Planning

South Bond Building - 105 Bond Street, Room 408

416.979.5000 ext. 6764

chris.desousa@ryerson.ca

If you have questions regarding your rights as a human subject and participant in this study, you may contact the Ryerson University Research Ethics Board for information.

Research Ethics Board

c/o Office of the Vice President, Research and Innovation

Ryerson University

350 Victoria Street

Toronto, ON M5B 2K3

416-979-5042

\section{Agreement:}

Your signature below indicates that you have read the information in this agreement and have had a chance to ask any questions you have about the study. Your signature also indicates that you agree to be in the study and have been told that you can change your mind and withdraw your consent to participate at any time. You have been given a copy of this agreement.

You have been told that by signing this consent agreement you are not giving up any of your legal rights.

Name of Participant (please print)

Signature of Participant

Date

Signature of Investigator

Date 
The survey you fill out, whether online or in hardcopy, will be confidential. PLEASE DO NOT PUT YOUR NAME ANYWHERE ON THE SURVEY. Participation in this study is voluntary. Your choice of whether or not to participate will not influence your future relations with Ryerson University. If you decide to participate, you are free to withdraw your consent and to stop your participation at any time without penalty or loss of benefits to which you are allowed.

\section{General Park Use Questions}

1. How often do you visit this park during the winter (end of November - beginning of March)? (Check One)

\begin{tabular}{|c|}
\hline $\begin{array}{l}\text { Every day } \\
\text { A few times ner week }\end{array}$ \\
\hline $\begin{array}{l}\text { A few times per week } \\
\text { Once a week }\end{array}$ \\
\hline
\end{tabular}

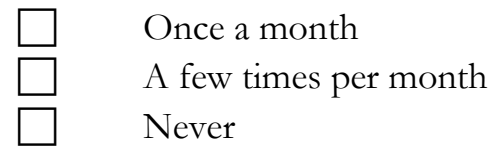

2. Who do you typically visit the park with? (Check all that apply)
$\square$ Family
$\square$ Friends
$\square \operatorname{Pet}(\mathrm{s})$

$\square$ Colleague(s)

$\square$ Other

3. How far do you travel to reach the park?

Kilometre(s)

4. From where do you typically travel from to visit the park? (Check one) $\square$ Work $\square$ Home $\square$ Other

5. How long do you stay in the park on a typical visit? Hour(s) (or minutes

\section{Exercise Questions}

6. How often do you exercise on a weekly basis? day(s) a week

7. How long do you spend on each workout? minute(s) (or) hour(s)

8. Are you a member at the gym? $\square$ Yes $\square$ No

9. Where do you typically exercise? $\square$ Gym $\square$ Home $\square$ Other

\section{Parks, Exercise and Health Questions:}

10. Do you visit the park during the winter months as part of your exercise or fitness routine? Yes $\square \quad$ No $\square \quad$ I do not exercise 
11. What type of activities do you engage in, in the park during the winter months, for your exercise routine, and how often:

\begin{tabular}{|l|c|c|c|c|}
\hline Activities & Never & Sometimes & Often & $\begin{array}{c}\text { I would like to, but } \\
\text { there are no facilities } \\
\text { here to engage in this } \\
\text { activity }\end{array}$ \\
\hline Walking/hiking & $\square$ & $\square$ & $\square$ & $\square$ \\
\hline Ice Hockey & $\square$ & $\square$ & $\square$ & $\square$ \\
\hline Jogging/running & $\square$ & $\square$ & $\square$ & $\square$ \\
\hline Cross-country skiing & $\square$ & $\square$ & $\square$ & $\square$ \\
\hline Snow-shoeing & $\square$ & $\square$ & $\square$ & $\square$ \\
\hline Skating & $\square$ & $\square$ & $\square$ & $\square$ \\
\hline Curling & $\square$ & $\square$ & $\square$ & $\square$ \\
\hline Sledding & $\square$ & $\square$ & $\square$ & $\square$ \\
\hline Other & $\square$ & $\square$ & $\square$ & $\square$ \\
\hline Other & $\square$ & $\square$ & $\square$ & $\square$ \\
\hline
\end{tabular}

12. Please rate the condition of the park facilities (washrooms, trails, facilities etc.) during the winter months: $\square$ Excellent

$\square$ Good

$\square$ Fair

$\square$ Poor

13. Do the conditions of the park affect the way you use the park for physical activity in the winter months? $\square$ Yes $\square$ No

14. If you answered YES to number 13, how and why do the park conditions affect your use of the park for physical activity during the winter? If you answered NO, what then are the factors that discourage you from exercising in the park during the winter?

15. What additions or improvements could be made to this park to encourage you to engage in physical activity here during the winter months? Why? 
16. Please describe any concerns you have about the park.

\section{Respondent Information}

The information below is for statistical purposes only.

17. What is your age?

18. What is your height? feet inches

19. What is your weight?

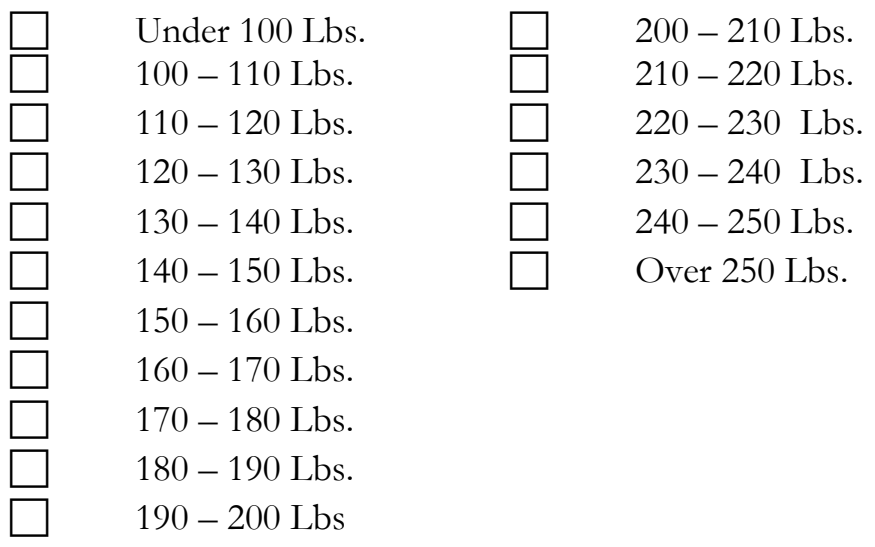

20. Are you $\square$ Male $\square$ Female

21. How do you identify your race/ethnicity?

$\begin{array}{ll}\square \quad & \text { White/European American } \\ \square \quad & \text { African American } \\ \square \quad & \text { Native American } \\ \square \quad & \text { Asian American } \\ \square \quad & \text { Latino/Hispanic } \\ \square \quad & \text { Multi-Racial } \\ \square \quad & \text { Other }\end{array}$

22. What was your total family income last year, before taxes?

Less than $\$ 15,000$

$\$ 15,000-\$ 25,000$

$\$ 25,000-\$ 50,000$

$\$ 50,000-\$ 75,000$

$\$ 75,000$ - $\$ 100,000$

More than $\$ 100,000$ 


\section{Works Cited}

Active Living Research, (2014). Physical Activity Resource Assessment (PARA) Instrument. Retrieved from http://activelivingresearch.org/node/10638.

Aresenault, L., \& Reid, J.W. (eds.). (2005). Proceedings from Dalhousie Faculty of Arhictecture and Planning: Welcoming Winter: Changing the Climate of Planning. Halifax, Nova Scotia.

Bai, H., Stanis, S.A., Kaczynski, A.T., Besenyi, G.M., (2013). Perceptions of neighbourhood park quality: Associations with physical activity and body mass index. Annals of Behavioural Medicine, 45, S39-S48.

Blanck, H.M., Allen, D., Bashir, Z., Gordon, N., Goodman, A., Merriam, D., Rutt, C. (2012). Let's go to the park today: The role of parks in obesity prevention and improving the public's health, Childhood Obesity. 8(5), 423-428.

Bedimo-Rung, A.L., Mowen, A.J., Cohen, D., (2005). The significance of parks to physical activity and public health: A conceptual model. American Journal of Preventative Medicine, 28, 159-168.

Board of Health, (2011). Staff report: Improving health and heath equity through the Toronto Parks Plan. Retrieved from http://www.toronto.ca/legdocs/mmis/2011/hl/bgrd/backgroundfile-42233.pdf

Boivin, D.N. (1988). Planning for better winter use of urban open spaces: A case study of Toronto's High Park [Unpublished dissertation]. Ryerson University: Toronto

City of Toronto, (2014a). Neighborhood Profiles. Retrieved from http://www1.toronto.ca/.

City of Toronto, (2014b). Parks and Recreation. Retrieved from http://www1.toronto.ca/wps/portal/contentonly?vgnextoid=5b1619f8602a0410 VgnV CM10000071d60f89RCRD\&WT.rd_id=parks

City of Toronto (2008). Distribution of low-income private households, 2006. Retrieved from http://www1.toronto.ca/city_of_toronto/social_development_finance_administration /files/pdf/da06_income_lico_private_households.pdf

Cohen, D.A., Ashwood, S., Scott, M., Overton, A., Evenson, K., Staten, L., Porter, D., McKenzie, T., Catellier, D. (2006). Public parks and physical activity among adolescent girls. Pediatrics, 118(5), e1381-e1389. 
Cohen, D.A., Golinelli, D., Williamson, S., Sehgal, A., Marsh, T., McKenzie, T.L. (2009). Effects of park improvements on park use and physical activity: Policy and programming implications. American Journal of Preventive Medicine, 37(6), 475-680.

Cohen, D., Han, B., Derose, K., Williamson, S., Marsh, T., Rudick, J., McKenzie, T.L. (2012). Neighborhood poverty, park use, and park-based physical activity in a Southern California city. Social Science \& Medicine, 75, 2317-2325.

Coleman, P. (January/February, 2010). The livable winter community. The Review, 10-14.

Coombes, E., Jones, A., \& Hillsdon, M. (2010). The relationship of physical activity and overweight to objectively measured green space accessibility and use. Social Science and Medicine, 70,816-822.

Floyd, M.F., Taylor, W.C., Whitt-Glover, M. (2009). Measurement of park and recreation environments that support physical activity in low-income communities of color. American Journal of Preventative Medicine, 36, S156-S160.

Gappert, G. (1987). Introduction: The future of winter cities. In G. Gapper [Ed]. The future of winter cities. Newbury Park, CA: Sage Publications.

GHK (2005). Measuring neighbourhood vitality: final report. Retrieved from http://www.urbancenter.utoronto.ca/pdfs/curp/SNTF_Neigh-Vitality_RP3.pdf.

Giles-Corti, B., Broomhall, M., Knuiman, M., Collins, C., Douglas, K., Ng, K., Lange, A.,\& Donovan, R. (2005). Increasing walking: How important is distance to, attractiveness, and size of public open space? American Journal of Preventative Medicine, 28(2S2), 169-176.

Glazier, R.H., Booth, G.L., Gozdyra, P., Creatore, M.I., Tynan, A.M. [Eds.], (2007). Neighbourhood environments and resources for health living - A focus on Diabetes in Toronto. Retrieved from http://www.ices.on.ca/Publications/Atlases-andReports/2007/Neighbourhood-environments-and-resources

Gordon-Larsen, P., Nelson, M.C., Page, P., Popkin, B.M. (2006). Inequality in the built environment underlies key health disparities in physical activity and obesity. Pediatrics, $117(2), 417-424$.

Han, B., Cohen, D., McKenzie, T.L. (2013). Quantifying the contribution of neighbourhood parks to physical activity. Preventive Medicine, 57, 483-487.

Icepark Group Inc., (2014). IceSkatePark Mississauga attitudinal survey report. Retrieved from http://www.iceparkgroup.ca/uploads/SURVEY_REPORT_For_Media__AUGUST_14_2013.pdf. 
Icepark Group Inc., (2013). Welcome to the IceSkatePark Initiative! Retrieved from http://www.iceparkgroup.ca/Home_Page.html

Kaczynski, A. \& Henderson, K. (2007). Environmental correlates of physical activity: A review of evidence about parks and recreation. Leisure Sciences, 29, 315-354.

Kaczynski, A. Potwarka, L., \& Saelens, B. (2008). Association of park size, distance, and features with physical activity in neighbourhood parks. American Journal of Public Health, 98(8), 1451-1456.

Kaczynski, A., Potwarka, L., Smale, B., \& Havitz, M. (2009). Association of parkland proximity with neighborhood and park-based physical activity: variations by gender and age.

Leisure Sciences An Interdisciplinary Journal, 31(2), 174-191.

Lee, R.E., Booth, K.M., Reese-Smith, J.Y., Regan, G., \& Howard, H.H. (2005). The Physical Activity Resource Assessment (PARA) instrument: Evaluating features, amenities and incivilities of physical activity resources in urban neighborhoods. International Journal of Behavioral Nutrition and Physical Activity, 2(13).

Lee, A.C.K., \& Maheswaran, R. (2010). The health benefits of urban green spaces: a review of the evidence. Journal of Public Health, 33(2), 212-222.

McCormack, G.R., Rock, M., Toohey, A.M., Hignell, D., (2010). Characteristics of urban parks associated with park use and physical activity: A review of qualitative research. Health \& Place, 16, 712-726.

McLean, D., Smith, H., Larsen, J. (1989). Winter recreation in large North American communities - a study. Journal of Physical Education, Recreation \& Dance, 60(8), 2057.

Moore, L.V., Roux A.V., Evenson, K.R., McGinn, A.P., \& Brines, S.J., (2008). Availability of recreational resources in minority and low socioeconomic status areas. American Journal of Preventive Medicine, 34(1), 16-22.

NPRA, (2011). Rethinking its urban parks: Denver capitalizes on winter climate to activate its parks year round. Parks and Recreation, 46(2), 11-13.

Powell, L.M., Slater, S., Chaloupka, F.J., \& Harper, D. (2006). Availability of physical activityrelated facilities and neighbourhood demographic and socioeconomic characteristics: a national study. American Journal of Public Health, 96(9), 1676-1680. 
Pressman, N. (1996). Sustainable winter cities: Future directions for planning, policy, design. Atmospheric Environment, 30(3), 521-529.

Pressman, N. (1988). Developing climate-responsive Winter Cities. Energy and Buildings, 11, $11-22$.

Pressman, N. (1987). The survival of winter cities: Problems and prospects. In G. Gappert [Ed.] The future of winter cities. Newbury Park, CA: Sage Publications.

Roemmich, J.N., Epstein, L.H., Raja, S., Yin, L., Robinson, J., Winiewicz, D. (2006). Association of access to parks and recreational facilities with the physical activity of young children. Preventive Medicine, 43, 437-441.

Sallis, J.F., Slymen, D.J., Conway, T.L., Frank, L.D., Saelens, B.E., Cain, K., Chapman, J.E. (2011). Income disparities in perceived built and social environment attributes. Health \& Place, 17, 1274-1283.

Simic, J. (2007). Winter recreation in the Canadian Rocky Mountains parks: Pilot Study. Parks Canada Agency. Retrieved from http://friendsofkootenay.ca/sites/default/files/Simic\%202007.pdf

Song, C., Joung, D., Ikei, H., Igarashi, M., Aga, M., Park, B.J., Miwa, M., Takagaki, M., \& Miyazaki, Y. (2013). Physiological and psychological effects of walking on young males in urban parks in winter. Journal of Physiological Anthropology, 32(18), n.p.

Tucker, P., \& Gilliland, J. (2007). The effect of season and weather on physical activity: A systematic review. Public Health, 121, 909-922.

Veitch, J., Ball, K., Crawford, D., Abbott, G.R., Psych, G., Salmon, J. (2012) Park improvements and park activity: A natural experiment. American Journal of Preventive Medicine, 42(6), 616-619.

Walljasper, J. (January/February, 2010). Winter communities show cold weather can be cool. The Review, 6-9.

Wen, M., Zhang, X., Harris, C.D., Holt, J.B., Croft, J.B. (2013), Spatial disparities in the distribution of parks and greenspaces in the USA, Annals of Behavioral Medicine, 45, S18-S27. 


\section{Photograph \& Vector References}

All photographs and illustrations by the author, Maria Bianchi.

Atkinson, N. (2010). Do Not Enter Vector. Retrieved from http://thenounproject.com/term/no/5613/.

Beynon, M. (2013). Gate Vector. Retrieved from http://thenounproject.com/term/gate/7288/.

Factoria.us Collective (2013). Snowman Vector. Retrieved from http://thenounproject.com/term/snowman/27372/.

Freid, G. (2012). Snowflake Vector. Retrieved from http://thenounproject.com/term/snowflake/11569/.

Hetteix, D. (2014). Snow Shovel Vector. Retrieved from http://thenounproject.com/term/snowshovel/32804/.

Hoffman, I. (2013). Walking Vector. Retrieved from http://thenounproject.com/term/walking/19727/.

Isabel, I. (2013). Duck Vector. Retrieved from http://thenounproject.com/term/duck/11061/.

Kleppe, E., (2013). Running Vector. Retrieved from http://thenounproject.com/term/running/14847/.

OCHA Visual Information Unit (2012). Bathroom Vector. Retrieved from http://thenounproject.com/term/bathroom/4340/.

Prado, L. (2013). Dog Vector. Retrieved from http://thenounproject.com/term/dog/12697/.

Wu, S. (2013). Tree Vector. Retrieved from http://thenounproject.com/term/tree/12101/. 